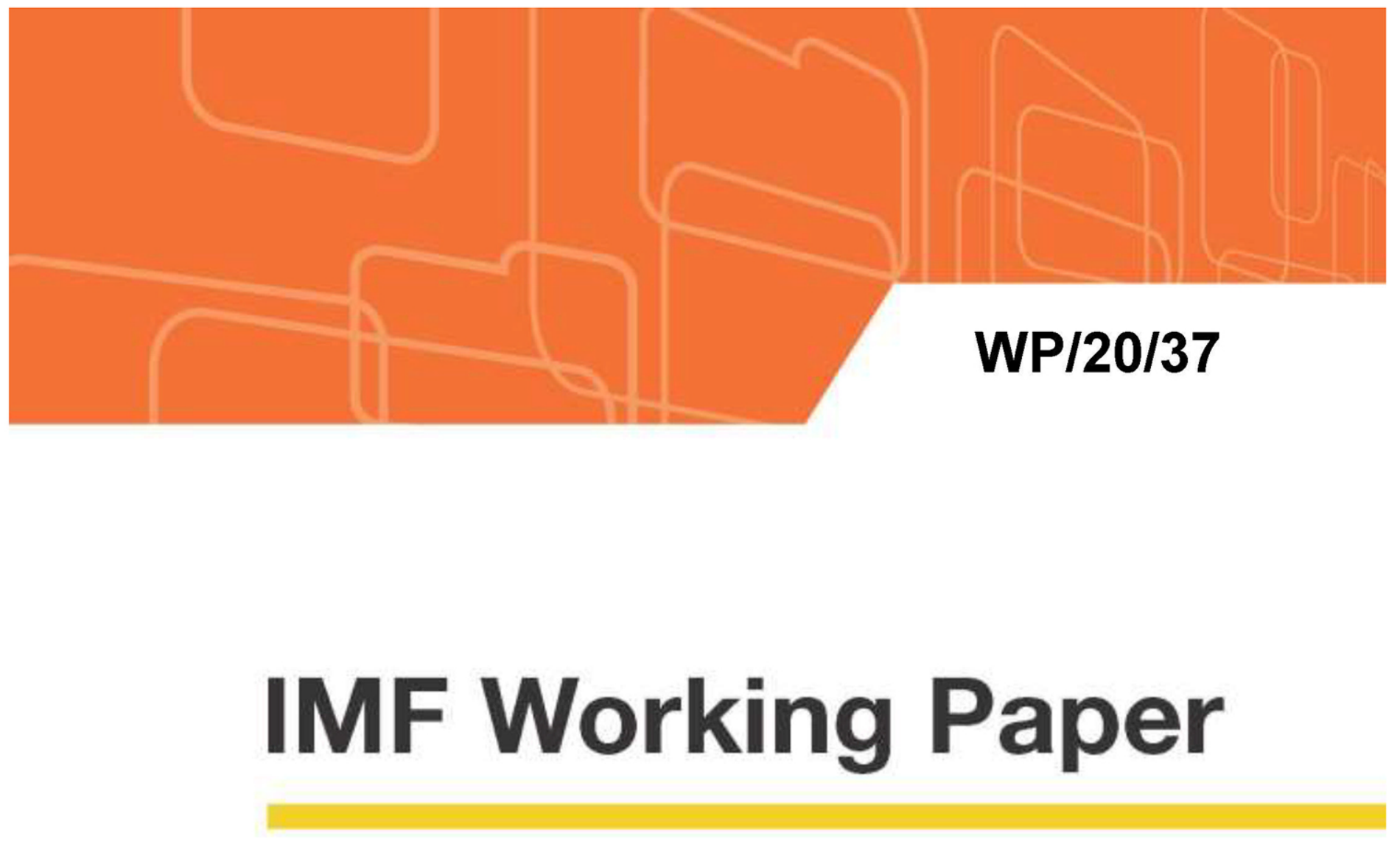

\title{
Toward a Comprehensive Tax Reform for Italy
}

by Emile Cammeraat and Ernesto Crivelli

IMF Working Papers describe research in progress by the author(s) and are published to elicit comments and to encourage debate. The views expressed in IMF Working Papers are those of the author(s) and do not necessarily represent the views of the IMF, its Executive Board, or IMF management. 


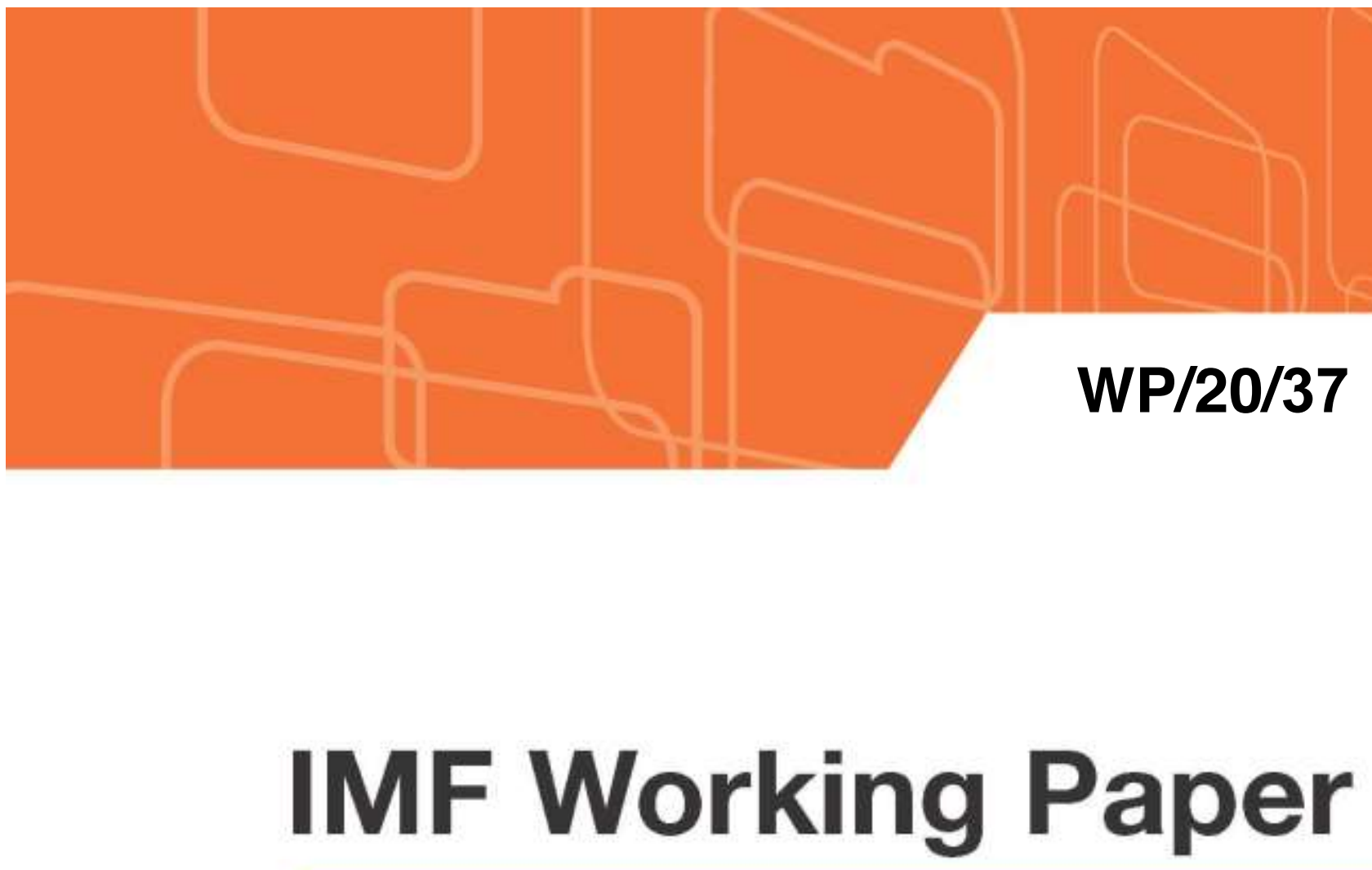

\section{Toward a Comprehensive Tax Reform for Italy}

by Emile Cammeraat and Ernesto Crivelli

IMF Working Papers describe research in progress by the author(s) and are published to elicit comments and to encourage debate. The views expressed in IMF Working Papers are those of the author(s) and do not necessarily represent the views of the IMF, its Executive Board, or IMF management. 


\title{
IMF Working Paper
}

European Department

\section{Toward a Comprehensive Tax Reform for Italy ${ }^{1}$ \\ Prepared by Emile Cammeraat ${ }^{2}$ and Ernesto Crivelli}

Authorized for distribution by Rishi Goyal

February 2020

IMF Working Papers describe research in progress by the author(s) and are published to elicit comments and to encourage debate. The views expressed in IMF Working Papers are those of the author(s) and do not necessarily represent the views of the IMF, its Executive Board, or IMF management.

\begin{abstract}
This paper evaluates elements of a comprehensive reform of the Italian tax system. Reform options are guided by the principles of reducing complexity, broadening the tax base, and lowering marginal tax rates, especially the tax burden on labor income. The revenue and distributional implications of personal income and property tax reforms are assessed with EUROMOD, while a microsimulation model is developed to evaluate VAT reform options. Simulations suggest that a substantial reduction in the tax burden on labor income can be obtained with a revenue-neutral base-broadening reform that streamlines tax expenditures and updates the property valuation system. In addition, a comprehensive reform would benefit lowand middle-income households the most, by lowering significantly their overall current tax liability, which results in increased progressivity of the tax system.
\end{abstract}

JEL Classification Numbers: D31, C63, R20, H20

Keywords: Italy, personal income tax, VAT, property tax, microsimulations, EUROMOD

Author's E-Mail Address: emile.cammeraat@oecd.org; ecrivelli@imf.org

\footnotetext{
1 This research project was completed during Emile's summer internship in the IMF's European Department. We are grateful to the Italian Ministry of Economy and Finance, Philip Barrett, Ruud de Mooij, Shafik Hebous, Cory Hillier, Davide Malacrino, and participants of seminars at the IMF and the Italian Ministry of Economy and Finance for many helpful suggestions.

2 OECD, Directorate for Science, Technology and Innovation and Department of Economics, Leiden University, Netherlands. The opinions expressed and arguments employed are those of the author, and do not represent the official views of the OECD or of its member countries.
} 
TABLE OF CONTENTS

CONTENTS

PAge

Abstract

I. INTRODUCTION $\underline{4}$

II. DATA AND METHODOLOGY $\underline{6}$

III. OVERVIEW OF THE CURRENT TAX SYSTEM

A. The Personal Income Tax (IRPEF)

B. The value-added tax (VAT)

C. The Immovable Property Taxes 14

IV. REFORM SCENARIOS AND SIMULATION RESULTS 17

A. Simulation of a Personal Income Tax Reform __ 17

B. Simulation of a VAT Reform __ 20

C. Simulation of a Property Tax Reform ___ 22

D. Distributive Effects of a Revenue-Neutral Shift in Taxation___ 26

V. CONCLUSIONS AND POLICY IMPLICATIONS

APPENDIX _— $\underline{30}$

REFERENCES ___ $\underline{35}$

Box

1. PIT Tax Expenditures in the European Union $\underline{9}$

FIGURES

1. Incidence of the PIT and Largest Tax Expenditures 10

2. Incidence of the VAT, Reduced Rates and Exemptions 12

3. Incidence of the Immovable Property Tax and Exemptions 15

4. Average Property Market Value, Assessment Ratio, and Household Income 16

5. Impact of PIT Reform Options 19

6. PIT Liability Before and After Reform 19

7. Impact of a Base-broadening Revenue Neutral VAT Reform $\underline{20}$

8. Impact of a Base-broadening VAT Reform for Higher Revenue $\underline{21}$

9. VAT Liability Before and After Reform $\frac{22}{24}$

10. Impact of a Base-broadening Revenue Neutral Property Tax Reform ___ 24

11. Impact of a Base-broadening Property Tax Reform for Higher Revenue __ 25

12. Property Tax Liability Before and After Reform $\underline{25}$

13. Impact of a Revenue-Neutral Shift from Income Tax to VAT

14. Impact of a Revenue-Neutral Shift from Income Tax to VAT and Property Tax __

15. Impact of a Revenue-Neutral Shift from Income to Property Tax $\underline{28}$

\section{TABLES}

1. Largest PIT Tax Expenditures $\underline{9}$

2. Household Consumption and VAT Rates 13 


\section{INTRODUCTION}

The Italian tax system is characterized by considerable complexity. This is reflected in the numerous options for taxpayers such as substitute taxes and special regimes, the multiple deductions and credits from the personal income tax, and more generally the range of tax expenditures that include reduced rates and exemptions for most taxes. All these contribute to the erosion of the tax base that results in significant revenue loss. For the personal income tax, the largest identified tax expenditures cause an estimated revenue loss of about 5 percent of GDP. For the value-added tax (VAT), reduced rates and exemptions contribute to a policy gap in Italy estimated at about 22 percent of the total tax liability (CASE, 2018), ${ }^{3}$ as compared to 16.5 percent for the EU average. It results in a revenue loss estimated at about $3 \frac{1}{2} 2$ percent of GDP.

Tax rates are very high in Italy, especially on labor income. To finance increasing public sector spending, while compensating for the revenue loss induced by the complexity of the system, marginal tax rates are among the highest in the EU. The average tax wedge on labor income ${ }^{4}$ in Italy is 47.9 percent, above the EU-15 average of 41.8 percent, and well above the OECD average of 35.9 percent. In addition, while the tax wedge on labor in EU-15 countries has declined by about 2 percent since 2000, it has increased in Italy by about 0.8 percent. The same can be concluded for other taxes: the corporate income tax rate of 24 percent is above the EU average of 21.3 percent, while the standard VAT rate of 22 percent is also slightly above the EU average. Moreover, the use of an outdated cadastral valuation system to determine property tax liabilities significantly erodes the tax base, while imposing a disproportionately high tax burden on the poor, which makes it a very unpopular tax.

A high implicit tax rate on labor is often said to be detrimental to growth and employment (IMF, 2015; Arnold and others, 2011; Myles, 2009). In general, the literature suggests that taxes levied on immovable property or consumption are less distortionary and thus, less harmful to economic growth than those levied on corporate or labor income (Mankiw and others, 2009; Slemrod, 1990). ${ }^{5}$ In that regard, there appears to be significant scope for shifting taxes to more growthfriendly revenue sources in Italy.

The combination of a complex tax system and high marginal tax rates can explain significant compliance gaps in Italy. Tax complexity increases opportunities for tax avoidance and evasion (Chetty and Saez, 2013; Abeler and Jaeger, 2015; Aghion and others, 2017). It also raises the

\footnotetext{
3 The VAT policy gap reflects deviations of the current tax rules from the benchmark-as a result of tax exemptions and reduced rates instead of a single standard rate for all goods and services (Keen, 2013). Here the policy gap measure (the "actionable" gap) excludes liability from the final consumption of imputed rents (the notional value of home occupancy by homeowners), financial services, and the provision of public goods and services, as charging them with VAT is impractical or beyond the control of national authorities.

4 The tax wedge is defined as the ratio between the amount of taxes and social security contributions paid (by both employees and employers) and the total cost of labor for the employer. The average tax wedge of 47.9 is computed for a single person earning an average income but the same pattern is observed across levels of income and types of households.

${ }^{5}$ Empirical studies for European and OECD countries (European Commission, 2006, 2010; Arnold and others, 2011; Andrle and others, 2018) found that a one percent of GDP shift from labor to property and consumption taxation increases long-term economic growth by 0.2-0.7 percentage points. The magnitude and robustness of the results, however, may vary depending on country sample and period considered (Baiardi and others, 2019).
} 
likelihood that taxpayers make unintentional mistakes in calculating their tax liabilities (Slemrod, 2018). Tax administrations need to devote increased resources and capabilities to keep pace with the tax system's growing complexity, while avoiding penalizing honest but overwhelmed taxpayers. This has inevitable consequences on the tax administration's ability to provide timely support and assistance to taxpayers, and to deter tax evasion through audits and compliance actions. Separately, a higher tax burden raises the incentive to underreport income. Several empirical studies confirm that higher tax rates discourage tax compliance and increase the size of the hidden economy (Freire-Seren and Panades, 2013; Chiarini and others, 2013; Pisani, 2014). In Italy, imperfect compliance (due to tax evasion) results in significant revenue loss. The VAT compliance gap has been estimated at about 26 percent of the total tax liability, as compared to about 12.3 percent for the EU average (CASE, 2018). For the personal income tax on the selfemployed, the gap is estimated at about 67 percent. The revenue loss from tax evasion has been estimated at about $€ 109$ billion or close to 6 percent of GDP (MEF, 2019a).

This paper assesses the elements of a comprehensive reform of the Italian tax system, with the objective of reducing the tax burden on labor income toward the EU average. The revenue and distributional implications of alternative reform options are simulated for the personal income tax, the VAT, and recurrent taxes on immovable property. Altogether, they account for 65 percent of tax revenue (19 percent of GDP). First, alternative reform options for the personal income tax are simulated that would result in a reduction in the tax wedge on labor income of about 4.5 percent-equivalent to 2 percent of GDP in budget revenue. ${ }^{6}$ Further, reform options for the value-added tax and the recurrent tax on immovable property are simulated in which the additional tax receipts are used to finance the reduction in labor income taxation-a revenueneutral tax reform. To assess revenue and distributional consequences, changes in pre- and postreform tax liability, as well as changes in household disposable income across the income distribution, are quantified for each tax.

Reform options are guided by the principles of reducing complexity, broadening the tax base, and lowering marginal tax rates. Simulations for a personal income tax reform aim at simplifying its current structure by reducing the number of taxable income brackets, while streamlining the number of credits and deductions. To lower the tax burden on labor income, a reduction in marginal tax rates is proposed, while preserving the progressivity of the current system. The distributional implications of an alternative flatter income tax reform are also assessed. Similarly, alternative VAT reforms are simulated, in which the number of reduced rates and exemptions are streamlined, in combination with a reduction in the standard rate. Finally, reform options for the tax on immovable property are simulated, in which the tax base is defined by the market value of the property and not by the cadastral value. This simulated revaluation allows for substantial tax rate reductions for comparable revenue.

Simulations for the personal income tax and tax on immovable property are carried out using EUROMOD, the microsimulation model for European Union member states. It applies national tax-benefit policy rules to harmonized microdata and calculates the effect of policy changes on

\footnotetext{
${ }^{6}$ The tax wedge on labor could be alternatively lowered by considering a reduction in the rate of social security contributions, which are also relatively high in Italy (IMF, 2019). This, however, would require a concomitant reform to the Notional Defined Contributions and healthcare schemes funded through social contributions.
} 
government revenue and household disposable income. This allows for inferences about the distributional effect of reforms. The Italian version of EU-SILC - the underlying dataset used in EUROMOD-however, does not contain detailed information on consumption expenditures needed for the simulation of VAT reforms. A microsimulation model is, therefore, developed following Sanchez and others (2016) using a statistical matching procedure that merges detailed data on consumption expenditures from the Italian Household Budget Survey into EU-SILC. This model is used to simulate the revenue and distributional implications of VAT reforms.

\section{DATA AND METHODOLOGY}

Policy reform simulations for the personal income and property taxes are performed on EUROMOD (version H1.0 + with software version V3.1.4), the tax-benefit microsimulation model for EU member states. It applies national tax-benefit policy rules to harmonized microdata and calculates the effect of policy changes on government revenue and household disposable income (Sutherland and Figari, 2013). This allows for inferences about the distributional effect of reforms. The Italian component of EUROMOD reproducing the 2018 Italian tax-benefit system has been validated through comparison with aggregate statistics provided by fiscal authorities (Ceriani, Figari, and Fiorio, 2018). We run all tax-benefit policy rules at their 2018 setting and then analyze the implications of simulated policy changes.

The underlying dataset used in EUROMOD is the European Union Statistics on Income and Living Conditions (EU-SILC). EU-SILC contains cross-sectional and longitudinal microdata on income, poverty, social exclusion, and living conditions. For our analysis, we use EU-SILC data of 2016, the latest available version. The Italian version of the EU-SILC dataset does not include detailed information on expenditures and consumption needed for the simulation of indirect taxes. As a result, therefore, EUROMOD in its current form cannot be used to analyze the effect of valueadded tax (VAT) or excise tax reforms, nor to simulate the effect of a tax shift from labor to consumption taxes.

To address this problem, a matching procedure is proposed, following Sanchez and others (2016), that imputes data on household expenditures into the EU-SILC database. Unfortunately, there is no micro-dataset available that contains both data on income and disaggregated data on consumption expenditure. The Italian Household Budget Survey (HBS) of 2017 from the Italian Institute of Statistics contains detailed data on consumption expenditure on 276 different goods and services, but not on income. ${ }^{7}$ The Survey on Household Income and Wealth (SHIW) of 2016 from the Bank of Italy contains data on income and consumption, but only at an aggregated level. Therefore, an indirect methodology is proposed to input disaggregated consumption data from the HBS into EU-SILC, by using as an external source the SHIW to match HBS consumption expenditure with income data. The imputation and matching strategy is based on the following steps:

- $\quad$ Estimating a consumption function using the SHIW dataset. A regression model is used to estimate aggregated household consumption expenditure (in logs) on

\footnotetext{
${ }^{7}$ It also contains detailed information on household social, economic, and territorial characteristics.
} 
disposable income (in logs) and a set of household-specific control variables or covariates that are also available in the EU-SILC dataset.

- Imputing aggregated household consumption in EU-SILC. The estimated parameters of the consumption function are used to predict aggregated consumption using disposable income (and household-specific control variables) in the EU-SILC dataset.

- $\quad$ Computing disaggregated household consumption shares in HBS. Households in the Italian HBS data report expenditures on 276 different goods and services. For the purpose of the analysis, the consumption data is aggregated into 12 different COICOP (Classification of Individual Consumption by Purpose) categories: 1) food and nonalcoholic beverages; 2) alcoholic beverages and tobacco; 3) clothing and footwear; 4) home fuels, electricity, rents (excluding imputed rents); 5) furniture and household services; 6) health; 7) transport; 8) communication; 9) recreation and culture; 10 ) education; 11) hospitality and catering; 12 ) other goods and services. The shares to total consumption expenditure are then computed for each of the 12 consumption categories, at the individual household level.

- $\quad$ Estimating disaggregated household consumption shares in EU-SILC. A statistical procedure is performed (using propensity score matching) to match individual households that share identical characteristics in both, the HBS and EU-SILC datasets. The matching procedure uses information on aggregated consumption (observed in the HBS and predicted in the EU-SILC dataset), as well as household-specific control variables. The computed disaggregated household consumption shares in HBS are imputed to their respective matched households in EU-SILC.

- $\quad$ Computing disaggregated household consumption in EU-SILC. The matched consumption shares are multiplied with total imputed consumption in EU-SILC to obtain household consumption levels for the 12 different consumption categories.

Once disaggregated household consumption is incorporated in the EU-SILC dataset, policy reform simulations for the VAT can be performed, and the revenue and distributional implications assessed. To obtain the VAT tax burden on consumption, weighted average VAT rates for each of the 12 COICOP consumption expenditure categories are computed, applying the current VAT rate structure in Italy to the most disaggregated number of 276 different goods and services reported in HBS.

Finally, EUROMOD is a static model and is currently not set up to evaluate second round and/or behavioral effects (for example, on labor supply or residential investment). As such, the results here show first-round budgetary and distributive effects. For the VAT simulations, however, an attempt is made to incorporate the effect of tax reforms on consumer behavior, following two simplified alternative approaches (as in Capeau, and others, 2014). One approach assumes fixed quantities, implying that consumed quantities are not affected by changes in prices, following the tax reform. Under this approach, consumption expenditure (and savings) is affected under the tax reform. A second approach assumes fixed expenditure shares, implying that total consumption expenditures are kept constant, and that expenditures for each good are adjusted so that each good's expenditure share is kept constant in the reform. 
Appendix I provides detailed information about the data sources, and the different steps in the imputation and matching procedure to incorporate household consumption to EU-SILC. It also presents several validation tests to assess the quality of estimations, and further implications of simulated tax reforms on revenue and income distribution.

\section{OVERVIEW OF THE CURRENT TAX SYSTEM}

As discussed in the introduction, the purpose of this paper is to assess the distributional and revenue effects of a comprehensive tax reform for Italy, allowing for a shift from labor to consumption and property taxes. This section provides details regarding the current design of the main taxes under scrutiny: the personal income tax, the value-added tax, and the property tax. The analysis here provides a baseline against which alternative reform scenarios will be assessed.

\section{A. The Personal Income Tax (IRPEF)}

The labor tax wedge in Italy is high. Labor income is subject to a progressive tax scale on five income brackets as follows: a starting rate of 23 percent applies for annual income between zero and $€ 15,000 ; 27$ percent to $€ 15,001-€ 28,000 ; 38$ percent to $€ 28,001-€ 55,000 ; 41$ percent to $€ 55,001-€ 75,000$; and 43 percent to income exceeding $€ 75,000$. Additional taxes are also due at the regional (1.23 percent to 3.33 percent) and local ( 0 to 0.9 percent) levels. The average tax wedge on labor for a single person earning an average income is 47.9 percent, above the EU-15 average of 41.8 percent. This pattern is observed across levels of income and types of households (IMF, 2018).

Taxes on labor, however, are applied on a rather narrow base. Italy offers about 140 tax deductions and credits on labor income (MEF, 2019b). Many of the largest identified tax expenditures are arguably desirable parts of a normal tax system, others could be reviewed and streamlined. Table 1 provides a description of the largest tax expenditures and their cost to the budget. The largest single item is a universal tax credit for income source that compensates for the lack of an income tax threshold, adding to the progressivity of the tax system. In fact, owing to this tax credit, employed labor income and pensions below $€ 8,150$, as well as self-employed incomes below $€ 4,100$, are "de facto" not subject to tax. In addition, contributions to welfare and pension schemes for employees can be deducted from the PIT. Given that pension income is taxed in Italy, this deduction is designed to avoid double taxation. Another item is the National Income Tax Bonus of $€ 80$ per month that is granted to employees with annual taxable income above $€ 8,000$, and linearly decreases for annual salaries between $€ 24,600-€ 26,600$. Several other tax credits are offered: family tax credits (for dependent spouses and children), for retirees, voluntary life insurance, education, mortgage interest payments, medical expenses, buildings refurbishment, etc. The cost to the budget of the largest identified PIT tax expenditures in 2018 has been estimated using EUROMOD at about $€ 89$ billion (5.1 percent of GDP), ${ }^{8}$ among the highest in the European Union (Box 1).

\footnotetext{
8 This paper uses a comprehensive definition of tax expenditures following Heady and Mansour (2019). The government's annual report on tax expenditures (MEF, 2018) follows a legal benchmark approach that excludes tax expenditures that are part of the tax structure such as the deduction on labor income and the exemption on contributions to welfare a pension schemes. The report estimates the cost of tax expenditures at about $€ 35$ billion, consistent with our more conservative estimate of about $€ 30$ billion using the same definition. The update of the report for the year 2020, estimates the cost at $€ 43$ billion (MEF, 2019).
} 


\begin{tabular}{|c|c|c|c|}
\hline \multicolumn{4}{|c|}{ Table 1. Largest PIT Tax Expenditures } \\
\hline \multirow[b]{2}{*}{ Description } & \multicolumn{2}{|c|}{ Revenue Loss } & \multirow[b]{2}{*}{ Comment } \\
\hline & $\begin{array}{l}\text { In billion } \\
\text { euro }\end{array}$ & $\begin{array}{l}\text { In percent } \\
\text { of GDP }\end{array}$ & \\
\hline $\begin{array}{l}\text { Tax credit for wage income from employment, } \\
\text { pensions, self-employment, and similar income. }\end{array}$ & 33.7 & 1.9 & $\begin{array}{l}\text { This regime is a substitute for the fact that Italy } \\
\text { has no lower personal income tax threshold. }\end{array}$ \\
\hline $\begin{array}{l}\text { Tax exemption for contributions to welfare } \\
\text { and pension schemes for employees and self- } \\
\text { employed. }\end{array}$ & 27.2 & 1.5 & $\begin{array}{l}\text { Pension contributions are excluded, and } \\
\text { pension income is taxed. Avoids double } \\
\text { taxation. }\end{array}$ \\
\hline Tax credit for dependent relatives. & 10.3 & 0.6 & $\begin{array}{l}\text { This benefit is sometimes considered a measure } \\
\text { ability to pay and part of the benchmark system } \\
\text { rather than a tax expenditure. }\end{array}$ \\
\hline National income tax bonus ( $€ 80$ bonus) & 8.0 & 0.5 & $\begin{array}{l}\text { Aimed at reducing the labor tax wedge at the } \\
\text { lower end of the income distribution. }\end{array}$ \\
\hline $\begin{array}{l}\text { Tax credit for building refurbishment and } \\
\text { construction. }\end{array}$ & 5.7 & 0.3 & Considered to have welfare objective. \\
\hline $\begin{array}{l}\text { Tax credit for medical expenses and health } \\
\text { assistance services. }\end{array}$ & 3.0 & 0.2 & Considered to have welfare objective. \\
\hline Tax credit on mortgage interest payments. & 1.2 & 0.1 & Considered to have welfare objective. \\
\hline Sum of largest PIT tax expenditures & 89.1 & 5.1 & \\
\hline
\end{tabular}

\section{Box 1. PIT Tax Expenditures in the European Union}

Tax expenditures are government revenues foregone as a result of differential or preferential treatment, relative to some benchmark system, of specific sectors, activities, regions, or agents. They can take many forms, including allowances (deductions from the base), exemptions (exclusions from the base), rate relief (lower rates), credits (reductions in liability), and tax deferrals (postponing payment).

European Union countries apply numerous tax expenditures in personal income taxation. Cross-country comparisons are difficult in practice due to different definitional, classification and benchmark approaches. Moreover, there are limited data available or reliable which would allow for comparing the use of tax expenditures in EU member states. Nevertheless, a comprehensive crosscountry analysis of tax expenditures (OECD, 2010) suggests that their budgetary cost is non-negligible, ranging from about $1 / 2$ percent of GDP in the Netherlands to close to 5 percent of GDP in Italy. This is not surprising given that tax expenditures are extensively used by governments as instruments for income redistribution as well as to encourage investment, employment and growth.

A more recent study (European Commission, 2016) assesses the revenue and distributive effects of four specific categories of preferential tax treatments affecting personal income taxation related to housing, pension, education, and health expenditures. For Italy, tax expenditures related to pensions include the deduction for contributions to the pensions scheme, the income tax credit on pension income, and the lower income tax on private pensions. Tax expenditures related to housing include the tax credit on mortgage interest payments and the tax credit for building refurbishment and construction. For health, the tax credit for medical expenses and health assistance services are considered. Simulations are carried out using EUROMOD, assuming that tax expenditures are eliminated in the reform scenario. The revenue loss due to only these categories of tax expenditures is estimated for Italy at about $3 \frac{1}{2}$ percent of GDP, among the highest in the EU (the average revenue loss among selected EU countries is estimated at about $2 \frac{1 / 2}{2}$ percent of GDP). 
The current structure of the Italian PIT is clearly progressive with respect to income. Based on its current design (tax rates, income brackets, and tax credits/deductions), the incidence of the PIT and its largest tax expenditures on different income groups is simulated in EUROMOD. For all Italian households, on average, the incidence of the PIT (net of tax credits and deductions) is about 20 percent of gross annual disposable income. The tax liability increases substantially with income, from about 2 percent of disposable income (about $€ 100$ ) in the first decile of the income distribution to about 29 percent (about $€ 26,000$ ) in the highest decile (Figure 1).

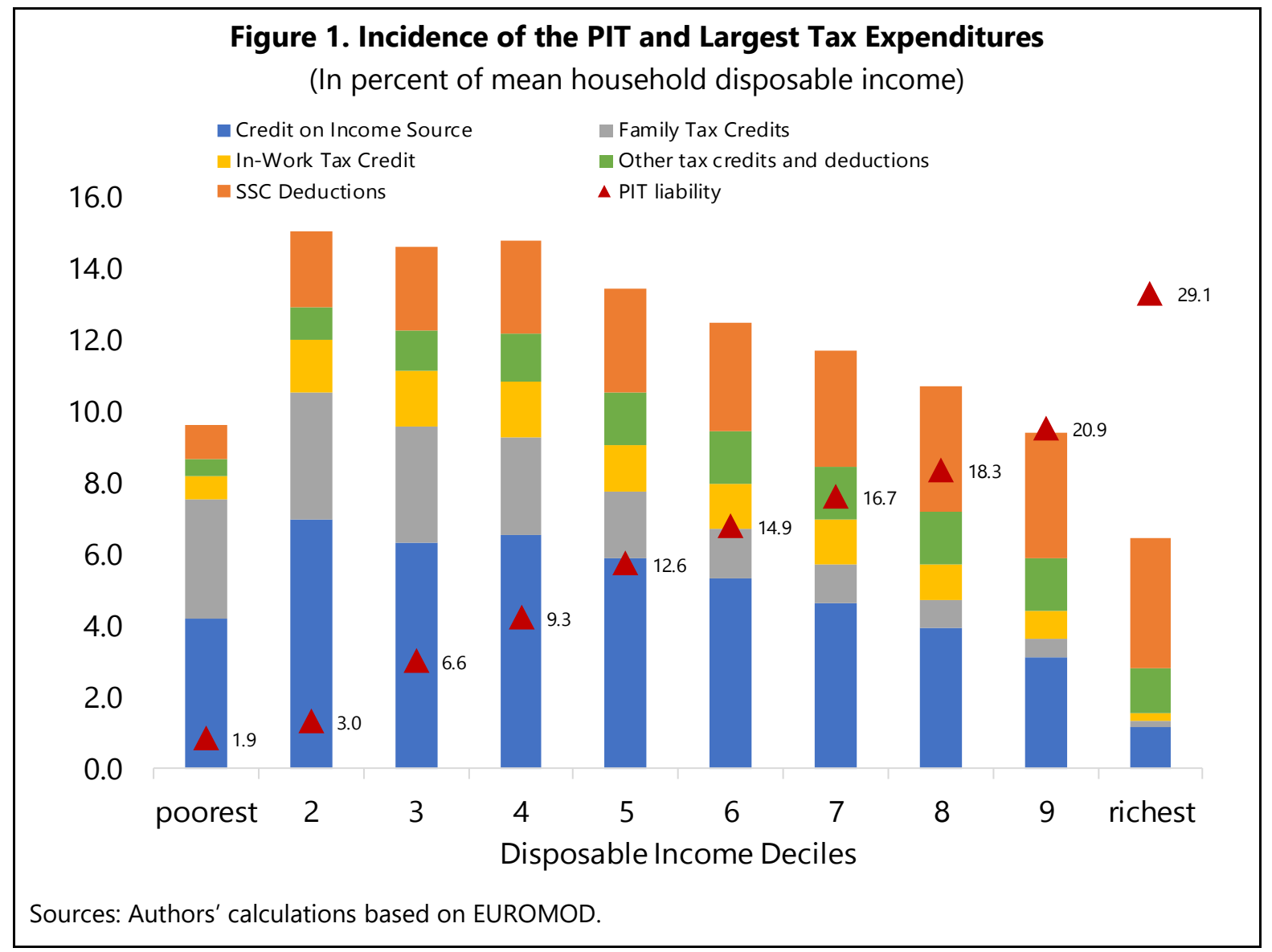

The interaction of multiple tax credits and deductions reduces to a great extent the incidence of the tax. Tax credits on income source as well as family tax credits contribute to the progressivity of the tax structure. Together, these two tax credits strongly reduce the incidence of the PIT for the first four deciles of the income distribution by increasing average household disposable income by about 10 percent. In contrast, their incidence on the three highest deciles falls below 4 percent. While desirable from a distributional perspective, family-related tax credits on dependent spouses may be undesirable from a labor supply perspective as it is an implicit subsidy for second income earners to remain outside of the labor market. The National income tax bonus is designed to benefit middle-income households the most. It increases disposable income of the second to seventh deciles by about 1.5 percent. Deductions for social security contributions, in contrast, reduce the progressivity of the tax structure by benefiting wealthy households relatively more. The contribution of this deduction to average household disposable income for the three highest income deciles (about 3.6 percent) doubles that of the first three 
deciles. Finally, several other tax credits and deductions (such as on building refurbishment, mortgage interest payments, or medical expenses), while costly in terms of revenue forgone, are not desirable from a distributional perspective. In fact, they tend to benefit wealthy households more, increasing disposable income from about 0.5 percent (first decile) to about 1.5 percent (highest deciles).

\section{B. The Value-Added Tax (VAT)}

Sales of goods and services not qualifying for a reduced rate or exemption are subject in Italy to a VAT standard rate of 22 percent. A reduced rate of 10 percent applies to selected goods including some food items, restaurants and hotels, pharmaceutical and medical products, energy products and recreational services. A reduced rate of 4 percent applies to food items, educational textbooks and newspapers, and school and company canteens. Exempt sales include actual rentals paid by tenants, dental, hospital, and other medical services, education, insurance, passenger transport (by sea, taxi, underground or tram), and postal services. While the standard VAT rate in Italy is above the EU-15 average of 21.6 percent, the widespread use of reduced rates and exemptions results in a significantly lower effective average VAT rate of about 10 percent, below the EU-15 average of 12 percent. These reduced rates and exemptions translate into a significant cost to the budget. Using the microsimulation model proposed in this paper, the revenue loss associated with taxing goods and services at a tax rate lower than the standard rate (the so-called policy gap) is estimated at about $€ 22$ billion (1.3 percent of GDP), and $€ 27$ billion (1.5 percent of GDP) for the reduced rates of 10 percent, and 4 percent, respectively. For the exempted goods, the revenue loss is estimated at about $€ 18$ billion ( 1 percent of GDP). These estimates are similar to those in Tyson (2014) and European Commission (2012a).

Equity concerns are one of the main reasons for taxing some goods and services at reduced rates. Poorer households tend to spend a larger share of their income on consumption than wealthier households, who tend to have a higher savings rate. Consequently, VAT payments disproportionally burden households at the bottom of the income distribution. The reduced rates therefore work to redistribute purchasing power from richer to poorer households softening the burden on the latter, thus making the VAT system less regressive (European Commission, 2012a). This notion is supported by the Italian data.

The incidence of the VAT is higher for poorer households (Figure 2). ${ }^{9}$ The VAT liability is estimated to decrease from about 12 percent of disposable income in the first two decile of the income distribution to below 9 percent for the highest deciles (Figure 2), in line with the findings in Curci and Savegnano (2019). In addition, the application of reduced rates and exemptions clearly reduces the incidence of the tax. Together, they increase disposable income by about 7 percent in the lowest deciles of the income distribution, ${ }^{10}$ while about 4 percent in the highest

\footnotetext{
${ }^{9}$ This conclusion no longer holds when the relationship between VAT payments and total consumption expenditures is considered (as discussed in IFS, 2011). Our estimates for Italy indicate that VAT payments in percent of household consumption increases from 12 to 13 percent from the lowest to the highest decile. In addition, wealthy households clearly pay more VAT (and benefit more from reduced rates and exemptions) when considered in absolute (euro) terms.

10 That is, without VAT reduced rates and exemptions, the VAT liability would be 7 percent higher for the lowest deciles, about 19 percent.
} 
deciles, which lowers the regressivity of the tax. The largest contribution to the lower tax incidence (and to the lower regressivity) comes from the application of the reduced rate of 4 percent, which increases disposable income of poorer families by about 3 percent, while only about 1 percent for the wealthiest.

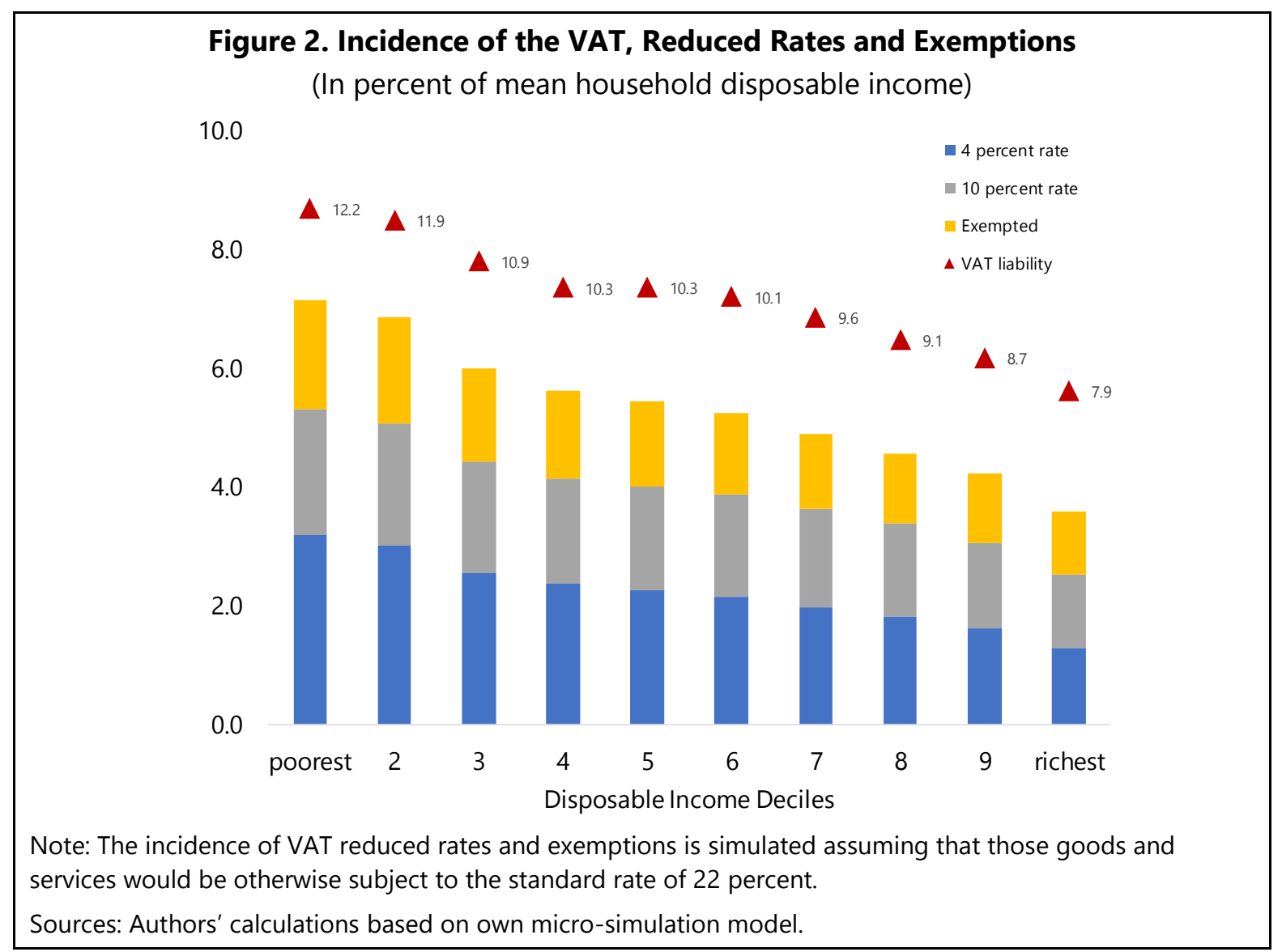

The application of reduced rates and exemptions in Italy is generally targeted to categories of goods largely consumed by poorer households. This is the case, for example, for basic foods (Table 2, Column 1), subject to an average VAT rate of 6.5 percent, ${ }^{11}$ where the poorer households consume the highest share of their income (about 30 percent), twice as high as the share consumed by the wealthiest households. Similarly, the reduced rate of 10 percent applied on energy products and drinking water together with the exemption on rental fees (Column 4) is targeted to benefit poorer households that consume about 20 percent of their income on these goods and services. Following a similar logic, categories of goods with an overall low consumption share (alcoholic beverages and tobacco, clothing, communications), or those for which consumption increases as a share of income (transport, recreation and culture), are subject to an average VAT rate equal or close to the standard rate of 22 percent. In contrast, the application of exemptions and reduced rates to some categories of goods does not seem to be well targeted. Especially the reduced rate of 10 percent applied on restaurants and hotel stays (Column 11) clearly benefits wealthy households the most.

\footnotetext{
${ }^{11}$ All goods in this category are subject to VAT rates of 4 percent and 10 percent.
} 


\begin{tabular}{|c|c|c|c|c|c|c|c|c|c|c|c|c|}
\hline \multicolumn{13}{|c|}{$\begin{array}{l}\text { Table 2. Household Consumption and VAT Rates } \\
\text { (As a share of household disposable income, by decile) }\end{array}$} \\
\hline & $\begin{array}{l}\text { Food and } \\
\text { non- } \\
\text { alcoholic } \\
\text { beverages }\end{array}$ & $\begin{array}{c}\text { Alcoholic } \\
\text { beverages } \\
\text { and } \\
\text { tobacco }\end{array}$ & $\begin{array}{l}\text { Clothing } \\
\text { and } \\
\text { footwear }\end{array}$ & $\begin{array}{l}\text { Home } \\
\text { fuels, } \\
\text { electricity, } \\
\text { rents }\end{array}$ & $\begin{array}{c}\text { Furniture } \\
\text { and } \\
\text { home } \\
\text { services }\end{array}$ & Health & Transport & Communication & $\begin{array}{l}\text { Recreation } \\
\text { and } \\
\text { culture }\end{array}$ & Education & $\begin{array}{l}\text { Hospitality } \\
\text { and } \\
\text { catering }\end{array}$ & Other \\
\hline & (1) & (2) & (3) & (4) & (5) & (6) & (7) & (8) & (9) & $(10)$ & $(11)$ & (12) \\
\hline Decile 1 & 30.7 & 2.5 & 4.7 & 23.3 & 4.6 & 6.8 & 7.8 & 4.1 & 4.2 & 0.3 & 3.6 & 7.4 \\
\hline Decile 2 & 29.0 & 3.1 & 4.3 & 22.1 & 4.9 & 6.2 & 8.7 & 3.7 & 4.1 & 0.4 & 3.6 & 7.2 \\
\hline Decile 3 & 24.4 & 2.2 & 4.7 & 18.9 & 5.0 & 5.5 & 8.0 & 3.2 & 4.3 & 0.4 & 4.0 & 7.3 \\
\hline Decile 4 & 22.5 & 2.2 & 4.6 & 17.0 & 3.7 & 4.9 & 9.3 & 2.9 & 4.1 & 0.5 & 4.3 & 6.9 \\
\hline Decile 5 & 21.2 & 2.1 & 4.7 & 15.7 & 3.7 & 5.2 & 9.3 & 3.0 & 5.0 & 0.4 & 4.7 & 7.0 \\
\hline Decile 6 & 20.0 & 2.0 & 4.7 & 13.6 & 3.9 & 4.6 & 10.6 & 2.9 & 4.7 & 0.5 & 5.0 & 7.2 \\
\hline Decile 7 & 18.3 & 2.1 & 4.8 & 11.7 & 4.4 & 4.2 & 10.0 & 2.7 & 5.0 & 0.5 & 5.1 & 6.6 \\
\hline Decile 8 & 16.8 & 1.8 & 4.6 & 10.7 & 4.3 & 3.9 & 9.6 & 2.5 & 4.7 & 0.5 & 5.0 & 6.7 \\
\hline Decile 9 & 14.7 & 1.6 & 4.4 & 9.7 & 3.3 & 4.0 & 10.4 & 2.1 & 5.0 & 0.6 & 4.9 & 6.6 \\
\hline Decile 10 & 11.3 & 1.3 & 4.1 & 7.5 & 3.4 & 3.4 & 11.0 & 1.5 & 5.2 & 0.7 & 4.6 & 6.1 \\
\hline VAT rate & 6.5 & 22.0 & 22.0 & 16.5 & 17.6 & 14.4 & 17.3 & 21.1 & 18.4 & 2.6 & 11.4 & 20.6 \\
\hline
\end{tabular}




\section{The Immovable Property Taxes}

The Italian tax on owned real estate is composed of two different taxes: a municipal tax on the ownership of the property (IMU), and the tribute for indivisible service (TASI), such as lighting and road maintenance. ${ }^{12}$ The main features of the tax can be summarized as follows:

- Tax base. The taxes are levied depending on the type of property. Properties classified as "main residence" (or owner-occupied houses) are currently exempt from IMU and TASI, unless they are luxury homes (stately homes, villas, castles and buildings with high artistic and historic value). Second homes (either vacant or rented), as well as commercial property are subject to both taxes. Rural land is only subject to IMU, except in the case of land owned by small independent farmers.

- $\quad$ Valuation system. The current property valuation system is based on estimates of market rental values from 1988-89. This is an estimate of what the "normal" rental value of the subject property would be as of 1988-89, which is the average value for similar properties in the same general location. It is based on basic characteristics such as location and building type (no information is used on the type of construction, building condition, or age of building). To address outdated property values, the government implemented an ad-hoc correction through the application of multiplicative factors to the tax base. First the cadastral value of all properties was increased by 5 percent (multiplied by 1.05). This amount was then further increased applying property-specific coefficients (1.6 for houses, and between 1.055-1.4 for other types of properties (commercial, industrial, land, etc.)).

- $\quad$ Tax rates. For the IMU, a basic tax rate of 0.76 percent is applied on the updated cadastral value, but each municipality has the flexibility to adjust the tax rate in the range between $0.46-1.06$ percent. For the TASI, the national standard rate is equal to 0.1 percent, and municipalities can adjust the rate in the range between $0-0.33$ percent. However, the sum of the IMU and TASI rates cannot exceed the maximum IMU rate.

The current design of the Italian tax on immovable property is regressive with respect to income. While revenue collection (essentially all from non-primary residences) is broadly in line with that of other advanced economies (about 1 percent of GDP in 2018), the property tax liability decreases with income, from about 5 percent of household disposable income in the first decile of the income distribution to about 2 percent in the highest deciles (Figure 3). The current exemption on main residences (equivalent to about 0.2 percent of GDP) contributes to a slightly less regressive tax structure, while reducing the overall incidence of the property tax. The exemption increases disposable income by about 0.9 percent in the lowest decile of the income distribution, while about 0.3 percent in the highest decile. That is, without the exemption, the incidence of the tax would increase to 5.7 percent of disposable income among poorer households, and to 2.4 percent among the wealthiest families.

\footnotetext{
12 In addition, municipalities charge a garbage tax (TARI) determined on the basis of the quantity and quality of waste produced or by productivity coefficients.
} 


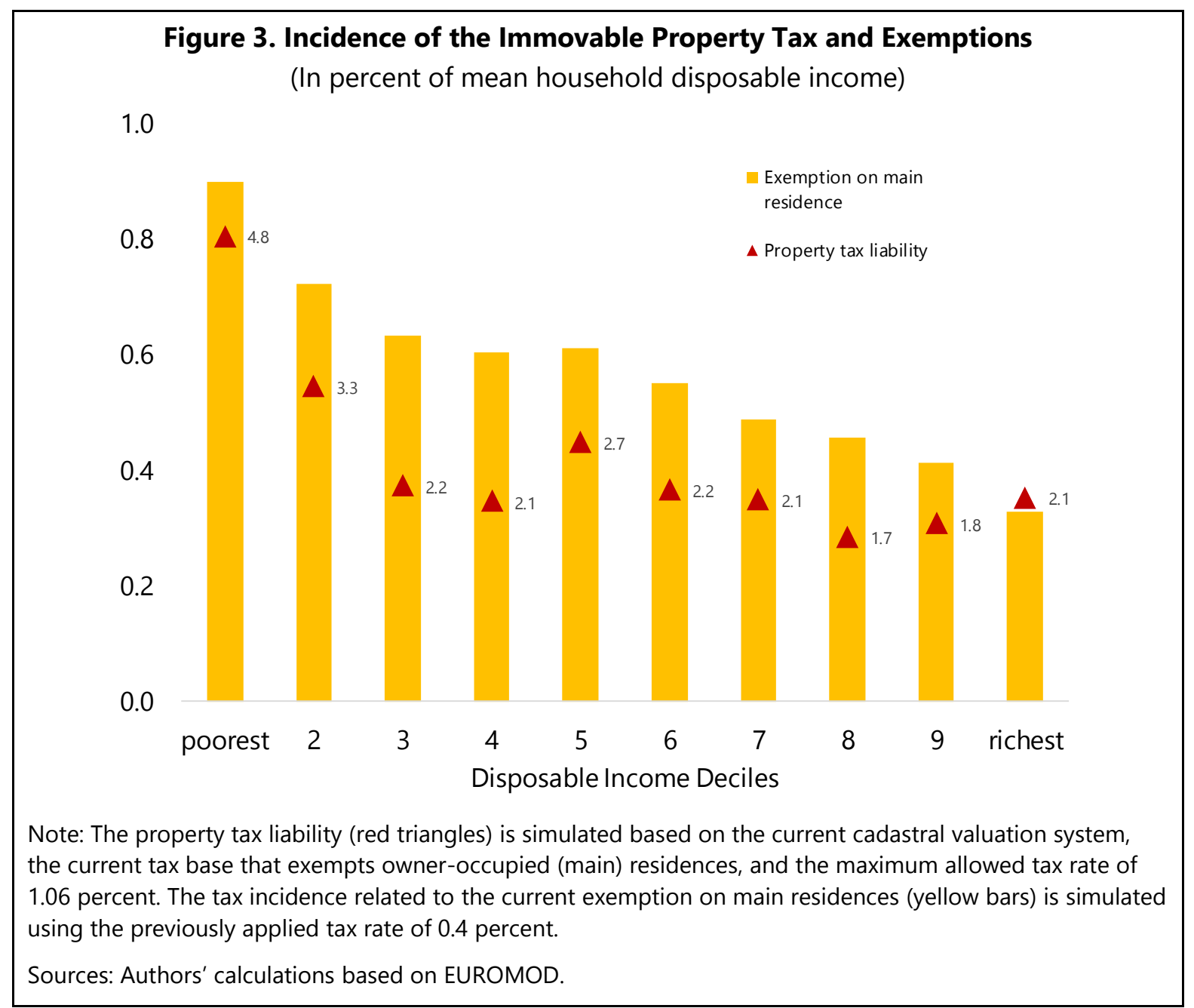

The current valuation system explains the regressive structure of the property tax (as discussed, for example, in IMF (2012)). Despite the revaluation (based on multiplicative factors), the taxable values of many properties remain well below market value. The national average ratio of market to taxable value is still 2.1 for primary residences and other dwellings, with a large variation across regions (Table 3 ). In addition, there is a strong negative relationship between the assessment ratios - the percentage of market value captured by the taxable value-and the average market value in each region (Figure 4.1). Since all housing property is subject to the same tax rate (within a class), the implication of this negative relationship is that, as the market value of properties increases, the effective average tax rate declines. Finally, there is, as expected, a positive relationship between household disposable income and the average market value in each region (Figure 4.2). As a result, the effective average tax rate declines with income. This asymmetry between market and taxable values, and the variability across the country, makes the current cadastral system unfair and inefficient. Common adjustment factors are not suitable to overcome disparities in assessed values and cannot address equity concerns. 
Table 3. Average Market Value of Housing and Ratio to Taxable Value

(By region, 2014)

\begin{tabular}{|c|c|c|c|c|}
\hline \multirow[b]{2}{*}{ Region } & \multicolumn{2}{|c|}{ Primary Dwelling } & \multicolumn{2}{|c|}{ Other Housing } \\
\hline & $\begin{array}{c}\text { Average } \\
\text { Market Value } \\
\text { (In euro) }\end{array}$ & $\begin{array}{l}\text { Ratio of Market } \\
\text { Value to } \\
\text { Taxable Value }\end{array}$ & $\begin{array}{c}\text { Average } \\
\text { Market Value } \\
\text { (In euro) }\end{array}$ & $\begin{array}{c}\text { Ratio of Market } \\
\text { Value to Taxable } \\
\text { Value }\end{array}$ \\
\hline Piemonte & 174,452 & 1.83 & 131,897 & 1.98 \\
\hline Valle d'Aosta & 292,764 & 2.26 & 177,661 & 2.36 \\
\hline Lombardia & 176,511 & 2.09 & 145,928 & 2.19 \\
\hline Trentino Alto Adige & 335,738 & 3.22 & 250,673 & 3.34 \\
\hline Veneto & 192,830 & 2.17 & 148,451 & 2.22 \\
\hline Friuli Venezia Giulia & 151,104 & 1.67 & 115,079 & 1.80 \\
\hline Liguria & 272,542 & 2.16 & 181,550 & 2.20 \\
\hline Emilia Romagna & 193,869 & 1.96 & 152,059 & 2.03 \\
\hline Toscana & 244,952 & 2.37 & 177,054 & 2.38 \\
\hline Umbria & 151,314 & 1.88 & 103,179 & 1.90 \\
\hline Marche & 172,195 & 2.35 & 116,595 & 2.35 \\
\hline Lazio & 268,392 & 2.02 & 171,616 & 2.06 \\
\hline Abruzzo & 148,172 & 1.84 & 94,951 & 1.82 \\
\hline Molise & 112,270 & 1.53 & 61,992 & 1.65 \\
\hline Campania & 205,549 & 2.29 & 138,059 & 2.32 \\
\hline Puglia & 138,398 & 1.72 & 88,318 & 1.75 \\
\hline Basilicata & 105,476 & 1.89 & 54,318 & 1.93 \\
\hline Calabria & 115,280 & 1.97 & 64,287 & 1.99 \\
\hline Sicilia & 142,927 & 2.07 & 89,312 & 2.11 \\
\hline Sardegna & 163,316 & 2.20 & 101,185 & 2.28 \\
\hline All Italy & 190,550 & 2.08 & 134,764 & 2.14 \\
\hline
\end{tabular}

Figure 4. Average Property Market Value, Assessment Ratio, and Household Income (By region, 2014)
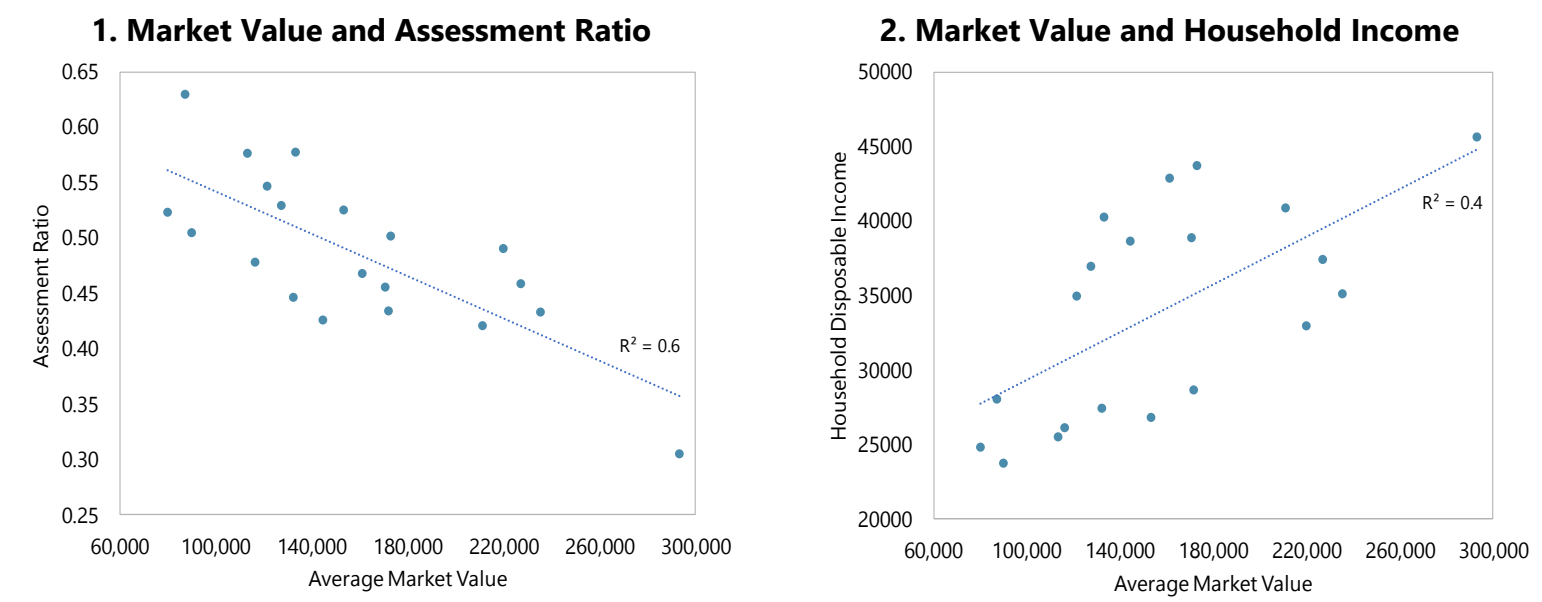

Sources: Authors' calculations.

Note: Data on market value (simple average of primary and other housing) as well as the assessment ratio (1/ratio of market to taxable value) taken from Table 3. Data on disposable income by region from SHIW. 


\section{REFORM SCENARIOS AND SIMULATION RESULTS}

In this section, a tax reform for Italy that shifts taxation from income to consumption and property is proposed. The revenue and income distribution effects of such a reform are simulated. The benchmark for the proposed reform, as discussed above, is a reduction in the overall tax burden on labor income in Italy toward the current average level of other EU-15 countries. To make this reform revenue-neutral, alternative reform options are proposed to increase the revenue from the VAT and property taxes. Reform options are guided by the principles of reducing complexity, broadening the tax base, and lowering marginal tax rates.

Reform scenarios:

- (1) Design options for a PIT reform. Simulations for a personal income tax reform aim at simplifying its current structure by proposing a reduction in the number of taxable income brackets, while streamlining the number of credits and deductions. To lower the tax burden on labor income, a reduction in marginal tax rates is proposed, while preserving the progressivity of the current system. Alternatively, the distributional implications of a flatter income tax reform are assessed. Alternative options are simulated for a PIT reform that targets an overall reduction in the tax wedge on labor income by 4.5 percentage points, the equivalent to 2 percent of GDP in budget revenue.

- (2) VAT and property tax reform. The implications of different combinations of VAT and property tax reform options are simulated to assess their revenue potential, as well as their impact on income distribution. For the VAT, reforms are simulated in which the number of reduced rates and exemptions are streamlined, in combination with a reduction in the standard rate. For the tax on immovable property, a revaluation of the tax base defined by the market value of the property is simulated. This simulated revaluation allows for substantial tax rate reductions for comparable revenue

- (3) Distributive effects of a revenue-neutral shift in taxation. Finally, the income distribution properties of a revenue-neutral shift in taxation away from labor income taxation is simulated for alternative VAT and property tax reform options.

\section{A. Simulation of a Personal Income Tax Reform}

Two alternative PIT reform options are evaluated that produce the same estimated average reduction in the tax wedge on labor of 4.5 percent. The net cost of the reform proposals to the budget is estimated at about $€ 36$ billion (2 percent of GDP).

Reform 1: A PIT reform for the low- and middle-income households. This reform aims at simplifying the PIT structure, while broadening the tax base and preserving the progressivity of the tax rate structure. ${ }^{13}$ The new tax structure reduces the number of tax brackets to four. It lowers the tax rate on the first taxable income bracket to 9 percent (from 23 percent), preserves

\footnotetext{
${ }^{13}$ Ceteris paribus, reducing the PIT rates typically increases income inequality as lower income groups pay no or little income tax due to the interaction of tax credits and deductions. As a result, even if only the tax rate on the lowest taxable income bracket is reduced, high income households benefit disproportionally more. To maximize the benefit to low- and middle-income households, while keeping the overall cost of the reform at 2 percent of GDP, the proposed reform significantly reduces the tax rate on the first taxable income bracket while increasing the tax rate on the highest taxable income brackets.
} 
the second bracket (income between 15,000-28,000) at 27 percent, increases the tax rate on the third bracket (for incomes between $28,000-55,000$ ) to 41 percent (from 38 percent), and merges the last two brackets into one bracket for income above 55,000 at 44 percent. In addition, the National Income Tax Bonus (the $€ 80$ bonus) and the tax credit for building refurbishment and construction are eliminated. ${ }^{14}$

This reform would benefit low- and middle-income households the most. Simulations using EUROMOD suggest that this reform would increase the disposable income of households between the third- and seventh-income deciles (with incomes between 20,000-40,000) by about 5.5 percent, twice as high as the benefit for the wealthiest households (Figure 5). While all households along the income distribution would pay lower taxes, middle-income groups get the highest reduction in PIT liability (Figure 6). In addition, households with incomes below 20,000 virtually pay no income tax due to the lower tax rate and the interaction of tax credits and deductions. In absolute (euro) terms, however, the proposed reform still benefits wealthier families more, as they pay a lower tax rate on the first part of their income. While annual disposable income increases by about $€ 820$ for the lowest five deciles of the income distribution, it increases by about $€ 1,600$ for the highest three deciles.

Alternative base-broadening options could be considered. The elimination of the National Income Tax Bonus, simulated with this reform option, may have the advantage of addressing labor-supply distortions created by the large variability of the effective marginal income tax rates that derive from regulatory stratifications (in part explained by the design of this tax credit) (Impact Assessment Office, 2017). The proposed elimination of the tax credit for building refurbishment and construction is motivated by equity considerations, given that it is a relatively costly tax expenditure that benefits wealthy households relatively more.

Reform 2: A flatter PIT reform. Several proposals (Baldini and Rizzo, 2018) have discussed the possibility of a flatter PIT structure with two tax brackets and lower tax rates. To assess the implications of such a reform, a flatter PIT reform option is simulated using a simplified structure consisting of two tax brackets: taxable income below 30,000 is subject to a tax rate of 15 percent, while taxable income above 30,000 is subject to a tax rate of 44 percent. As in the previous reform proposal, the cost of this reform is compensated with the elimination of the National Income Tax Bonus and the tax credit for building refurbishment and construction. In contrast to the previous reform, this flatter PIT structure is clearly more regressive. Figure 5 shows how this flatter PIT reform compares with the proposed reform above. In absolute (euro) terms, the flatter reform benefits wealthier families significantly more. It increases average annual disposable income of households in the first five deciles of the income distribution by about $€ 530$, while by about $€ 2,700$ for the highest three deciles. When assessed relative to disposable income, the flatter PIT also benefits wealthier families relatively more than in the previous reform-thus lowering their resulting tax liability. Disposable income of middle-income households is estimated to increase by about 3.5 percent, while it increases by about 5 percent among the highest three deciles. Simulations suggest that an even flatter PIT reform proposal (for instance, with rates at 15 and 20 percent) would be exponentially costlier to the budget, and highly regressive (IMF, 2019).

\footnotetext{
${ }^{14}$ The proposed changes to the tax structure (tax brackets and rates only) have a cost to the budget estimated at about $€ 50$ billion. The elimination of the National Income Tax Bonus and the tax credit on refurbishment and construction produce savings of $€ 8.0$ billion, and $€ 5.7$ billion, respectively.
} 
Figure 5. Impact of PIT Reform Options

(Change in mean household disposable income)

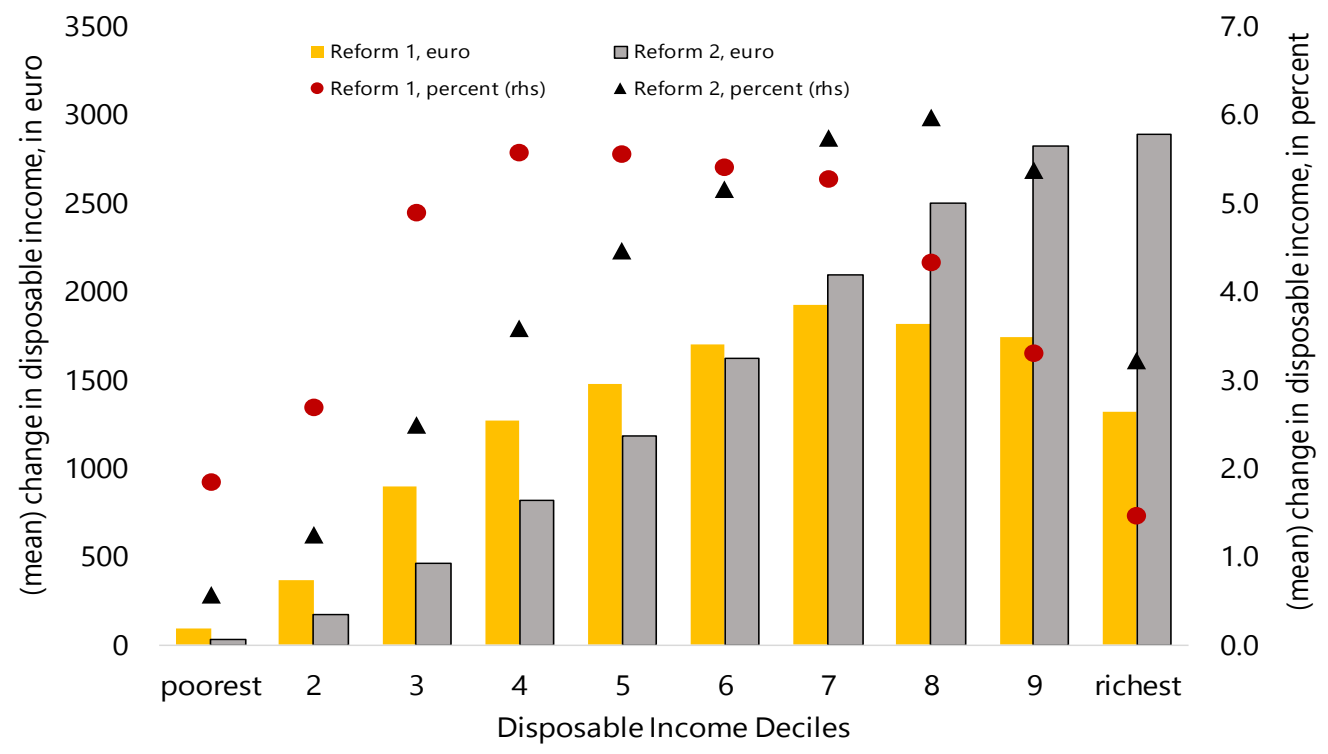

Note: This chart displays the change in the PIT liability as a result of the proposed reform, measured as the change in disposable income both in monetary values (euro); and as in percentage of disposable income.

Sources: Authors' calculations based on EUROMOD.

\section{Figure 6. PIT Liability Before and After Reform}

(In percent of household disposable income)

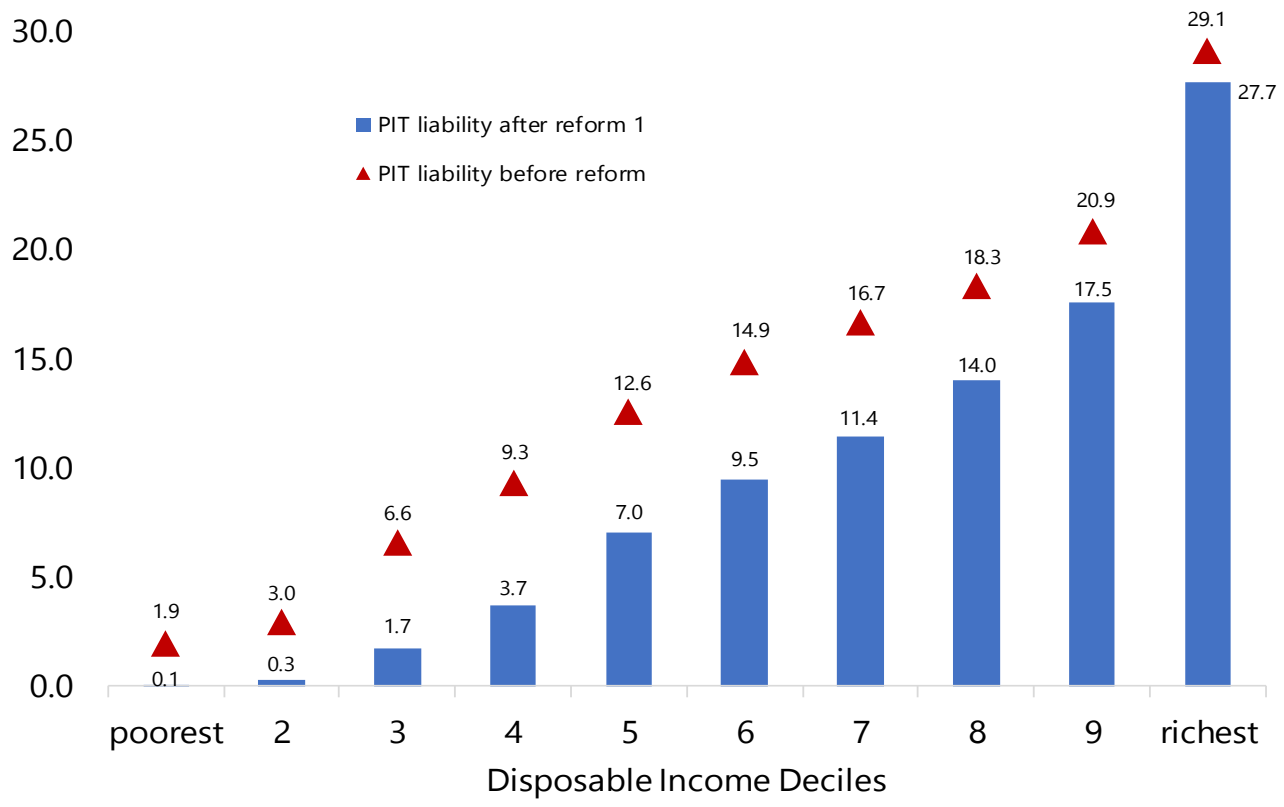

Sources: Authors' calculations based on EUROMOD. 


\section{B. Simulation of a VAT Reform}

Base-broadening VAT reform options are evaluated, in combination with changes to the standard VAT rate. The proposed reforms are designed to generate additional revenue to the budget in order to compensate half- or the full cost of the income tax reform (1-2 percent of GDP), while minimizing the impact on the poorer households. ${ }^{15}$

A base-broadening revenue-neutral VAT reform. As a benchmark for further reforms, the income distribution implications of a revenue neutral VAT reform are first simulated. Two alternative base-broadening reform alternatives are considered: eliminating the reduced rate of 4 percent in combination with a reduction of the standard rate to 17.5 percent; and eliminating the reduced rate of 10 percent in combination with a reduction of the standard rate to 18.5 percent. The standard rate reduction has been calibrated to simulate a revenue neutral reform in both cases.

A base-broadening revenue-neutral VAT reform that eliminates the reduced rate of 10 percent (and lowers the standard rate to 18.5 percent) is largely neutral for income distribution (Figure 7). Disposable income-and thus the VAT liability—is mostly unchanged along income levels. In contrast, a revenue-neutral reform that eliminates the reduced rate of 4 percent (and lowers the standard rate to 17.5 percent) is regressive. It redistributes income from poorer to wealthier

\section{Figure 7. Impact of a Base-broadening Revenue Neutral VAT Reform}

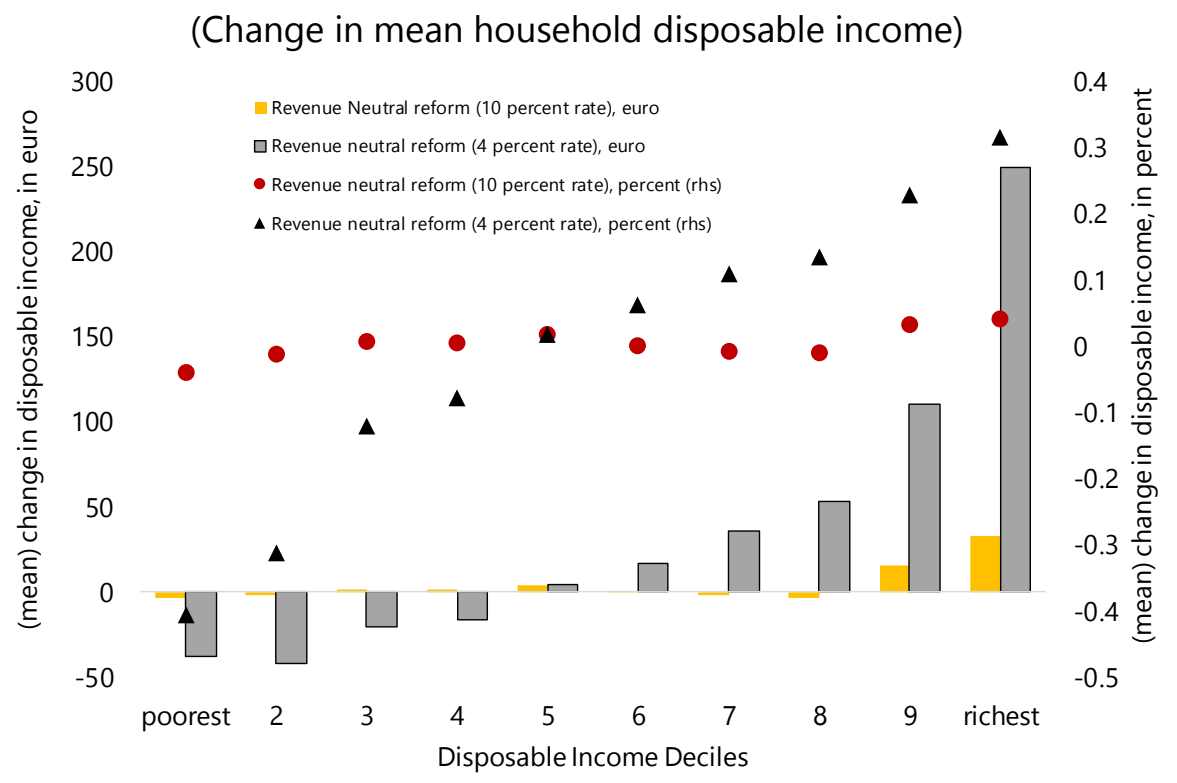

Note: This chart displays the change in the VAT liability as a result of a revenue-neutral reform, measured as the change in disposable income both in monetary values (euro); and as in percentage of disposable income. The revenue-neutral reform is calibrated assuming that goods and services currently subject to either the reduced rate of 4 percent (or 10 percent) are now subject to the proposed standard rate of 17.5 percent (or 18.5 percent).

Sources: Authors' calculations based on own micro-simulation model.

15 The revenue implications of VAT tax reforms differ somewhat (0.1-0.3 percent of GDP) depending on the extent to which households modified their consumed quantities in response to price changes. For the simulations, reform options are calibrated to generate the target revenue in the mid-point between the two alternative approaches (fixed quantities and fixed expenditure shares). 
households by an estimated 0.4 percent of disposable income. In absolute (euro) terms, the reform reduces the disposable income of the two lowest deciles by about $€ 50$, while it increases that of the highest decile by about $€ 250$. As indicated in Section III.B, this result is explained by the fact that the reduced rate of 4 percent is targeted to categories of goods largely consumed by poorer household. This is not always the case for the reduced rate of 10 percent, thus eliminating it in combination with a reduction in the standard rate has a relatively neutral impact on income distribution.

A base-broadening VAT reform for higher revenue. Two alternative reforms are simulated: eliminating the reduced rate of 10 percent in combination with a reduction of the standard rate to 21 percent, to generate additional revenue of about 1 percent of GDP; and eliminating the reduced rate of 10 percent in combination with an increase of the standard rate to 24 percent, to generate additional revenue of about 2 percent of GDP. ${ }^{16}$

Revenue-increasing VAT reforms are regressive, and the negative impact on income distribution increases proportionally with revenue. A VAT reform that targets a 1 percent of GDP in additional revenue reduces disposable income of poorer households (in the first two deciles) by about 1.5 percent (Figure 8), while slightly below 1 percent for wealthier households (highest two deciles).

Figure 8. Impact of a Base-broadening VAT Reform for Higher Revenue

(Change in mean household disposable income)

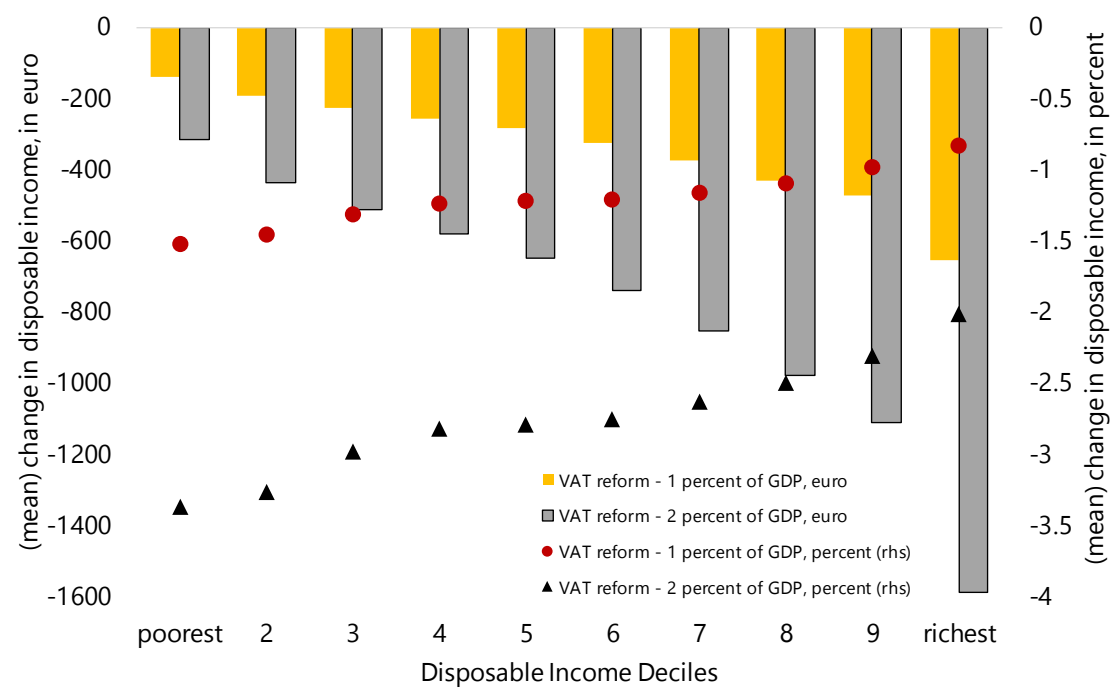

Note: This chart displays the change in the VAT liability as a result of the proposed reform, measured as the change in disposable income both in monetary values (euro); and as in percentage of disposable income. The reform is calibrated assuming that goods and services currently subject to the reduced rate of 10 percent are now subject to the proposed standard rate of 21 percent or 24 percent, respectively. The reduced rate of 4 percent, as well as exempted goods remained unchanged under the proposed reform.

Sources: Authors' calculations based on own micro-simulation model.

\footnotetext{
${ }^{16}$ In addition, a reform option was calibrated to simulate the safeguard clause in the Italian 2019 budget, that envisaged an increase of the standard rate to 25.2 percent, in combination with an increase of the reduced rate of 10 percent to 13 percent. The revenue impact of this reform is estimated at 1.3 percent of GDP, identical to estimates reported by the Italian authorities (BOI, 2019). The distributive effects are slightly worse than those obtained for the proposed reform (for a 1 percent of GDP in additional revenue). For poorer households, disposable income decreases by about 1.7 percent, while for wealthier households it decreases by about 1.2 .
} 
This would translate into a resulting VAT liability of close to 14 percent of household disposable income among poorer households, while about 9 percent among wealthier households (Figure 9). The impact of a VAT reform that targets a 2 percent of GDP in additional revenue is roughly twice as high as in the previous reform. In absolute (euro) terms, however, the reform affects wealthier families the most. Poorer households pay additional VAT estimated at $€ 150$ ( $€ 300$ in the 2 percent of GDP reform), while wealthier households pay additional VAT estimated at about $€ 700$ ( $€ 1,500$ in the 2 percent of GDP reform).

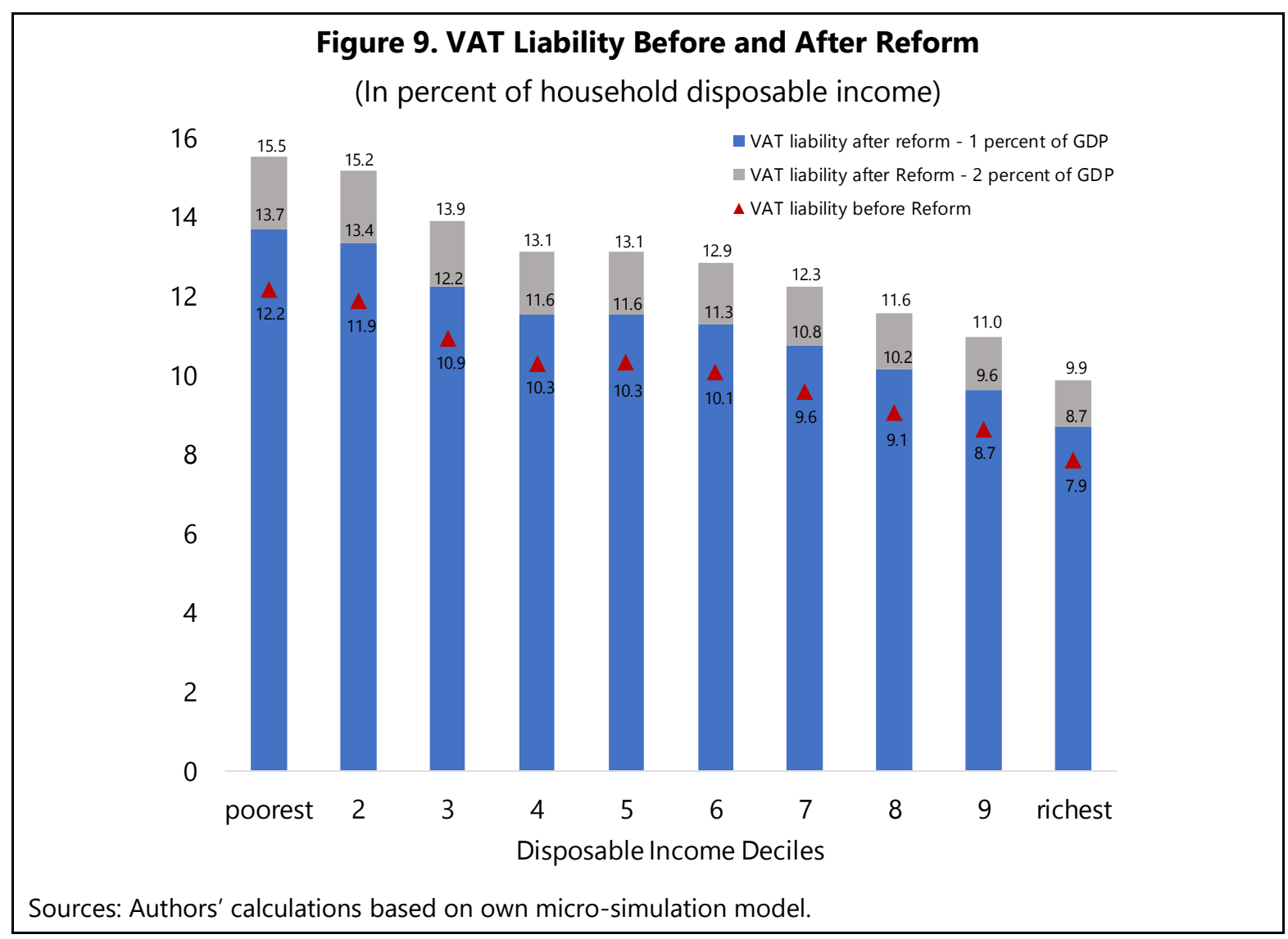

\section{Simulation of a Property Tax Reform}

Reform options to recurrent property taxes are evaluated, considering base-broadening measures, and improvements to the valuation system combined with tax rate reductions. The proposed reform is designed to generate additional revenue to the budget in order to compensate half- or the full cost of the income tax reform (1-2 percent of GDP), while minimizing the impact on the poorer households.

Valuation system linked to market value. As indicated in Section III.C, the current taxable value of properties defined by the cadastral value remains well below market value. To simulate the implications of a valuation system reform, the current taxable values reported in EU-SILC are multiplied by the ratio of market to taxable value of properties (reported in Table 3). For the purpose of the simulation, the same ratio applies to all properties in a given geographical region. 
The updated taxable value of properties used in the reform simulations is thus obtained as follows:

$$
{\text { Taxable } \text { Value }_{i}=\text { Cadastral Value }_{i} \times 1.05 \times 1.60 \times \text { Ratio }_{i}}
$$

Where $i$ are the 20 geographical regions in Italy; multiplicative factors $(1.05 ; 1.6)$ are applied to all properties as in the current system; and the ratio reflecting the remaining gap between market and taxable values is applied according to the geographical region.

A base-broadening revenue-neutral property tax reform based on market valuation. As a benchmark for further reforms, the income distribution implications of a revenue neutral property tax reform are first simulated. Using EUROMOD, a reform is simulated in which all immovable property is subject to the tax (including owner-occupied main residences), and the valuation system is based on market value (simulated based on the methodology presented above).

The current property tax revenue can be obtained with a significantly lower tax rate. As a result of the broadening of the tax base to include main residences and the improvement of the valuation system, the current revenue from the property tax on immovable property (about 1 percent of GDP in 2018) can be obtained with a tax rate of 0.3 percent. This compares to the current maximum allowed tax rate of 1.06 percent for other residences; and the previously applied 0.4 percent on main residences. ${ }^{17}$

A revenue-neutral property tax based on market valuation significantly improves income distribution. The disposable income of poorest households increases by 3 percent, while it decreases by 0.5 percent among wealthier households. As a result of market valuation, the property tax liability correspondingly decreases substantially among poorer households (Figure 10). Households in the first decile pay property tax of about 2 percent of their disposable income, as compared to 4.8 before the reform. This results in annual savings of about $€ 275$. For wealthier households (in the two highest deciles), the tax liability increases from about 2 percent to 2.6 percent, resulting in higher annual property taxes for about $€ 460$. Needless to say, however, property taxes can be a burden on highly indebted or liquidity-constrained households. While the design should remain simple and applied uniformly on a broad base, one efficient solution to address liquidity issues is to offer certain households a deferral scheme, where the tax liability becomes payable only when the property is transferred (for instance through sale or inheritance).

\footnotetext{
17 While cross-country comparisons are difficult due to differences in valuation systems and taxation regimes, tax rates on immovable property for countries in the European Union range between $0.4-1$ percent, on average (European Commission, 2012b).
} 
Figure 10. Impact of a Base-broadening Revenue Neutral Property Tax Reform

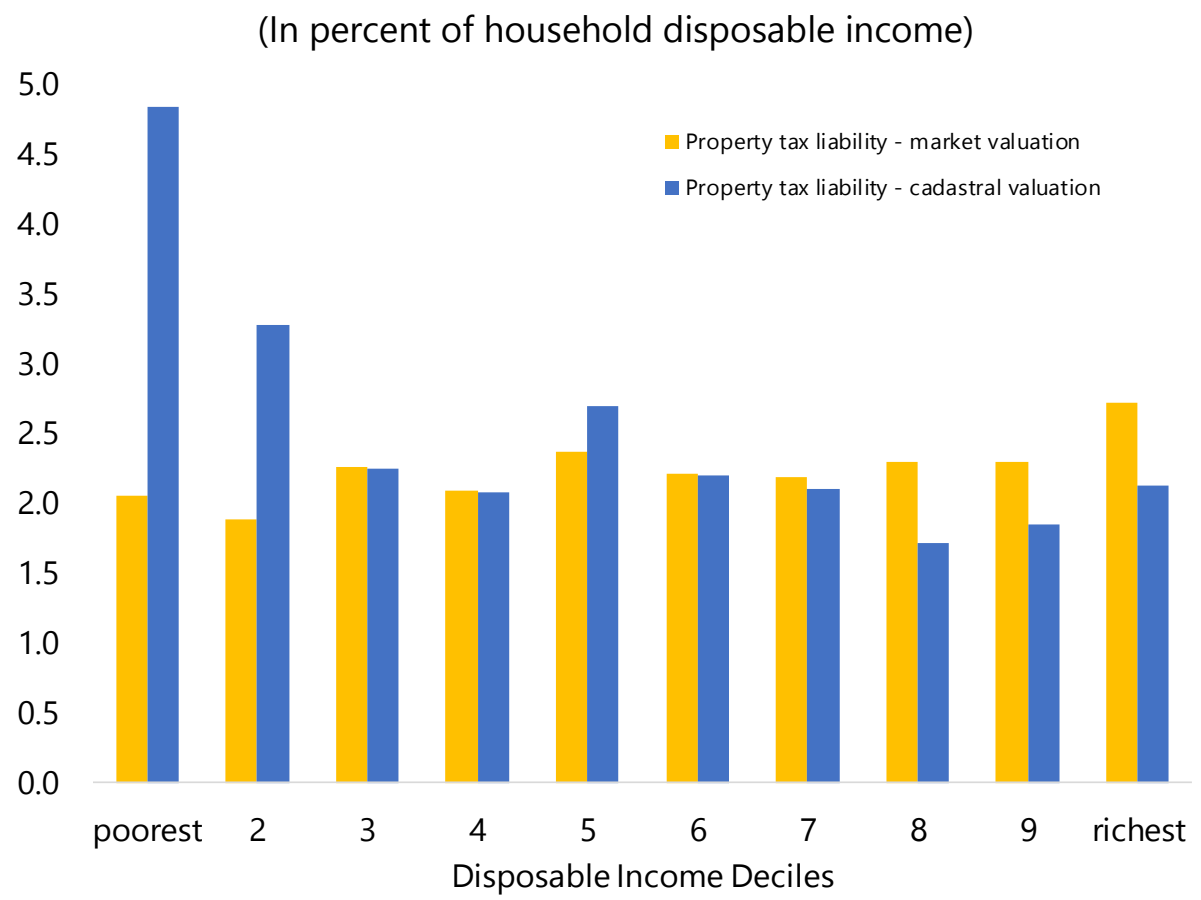

Note: Simulations for market-based valuation use a tax rate of 0.3 percent on all properties to obtain the current property tax revenue of 1 percent of GDP. Simulations for cadastral valuation reflect the current system (that generates tax revenue of 1 percent of GDP), based on the current valuation system, the current tax base that exempts owner-occupied (main) residences, and the maximum allowed tax rate of 1.06 percent. Sources: Authors' calculations based EUROMOD.

A base-broadening property tax reform for higher revenue. Two alternative reform alternatives are simulated assuming again that all immovable property is subject to the tax (including the main residence), and the valuation system is based on market value. All property is subject to a tax rate of 0.55 percent to generate additional revenue of about 1 percent of GDP. Alternatively, all property is subject to a tax rate of 0.8 percent to generate additional revenue of about 2 percent of GDP.

Revenue-increasing property tax reforms based on market valuation increase the progressivity of the tax. A property tax reform that targets a 1 percent of GDP in additional revenue increases disposable income of households in the first decile of the income distribution by 0.8 percent (Figure 11). Disposable income decreases from 1 percent in the second decile to about 3 in the highest decile. This would translate into a resulting property tax liability that increases with disposable income from 4 percent to above 5 percent (Figure 12). The impact of a property tax reform that targets a 2 percent of GDP in additional revenue is roughly twice as high as in the previous reform, with disposable income decreasing from 0.5 percent in the first decile to 5 percent in the highest decile. In absolute (euro) terms, the reform affects wealthier families the most. Poorer households (in the first two deciles) pay additional property tax estimated at $€ 30$ ( $€ 120$ in the 2 percent of GDP reform), while wealthier households (in the highest two deciles) pay additional property tax estimated at about $€ 1,700$ ( $€ 2,900$ in the 2 percent of GDP reform). 
Figure 11. Impact of a Base-broadening Property Tax Reform for Higher Revenue

(Change in mean household disposable income)

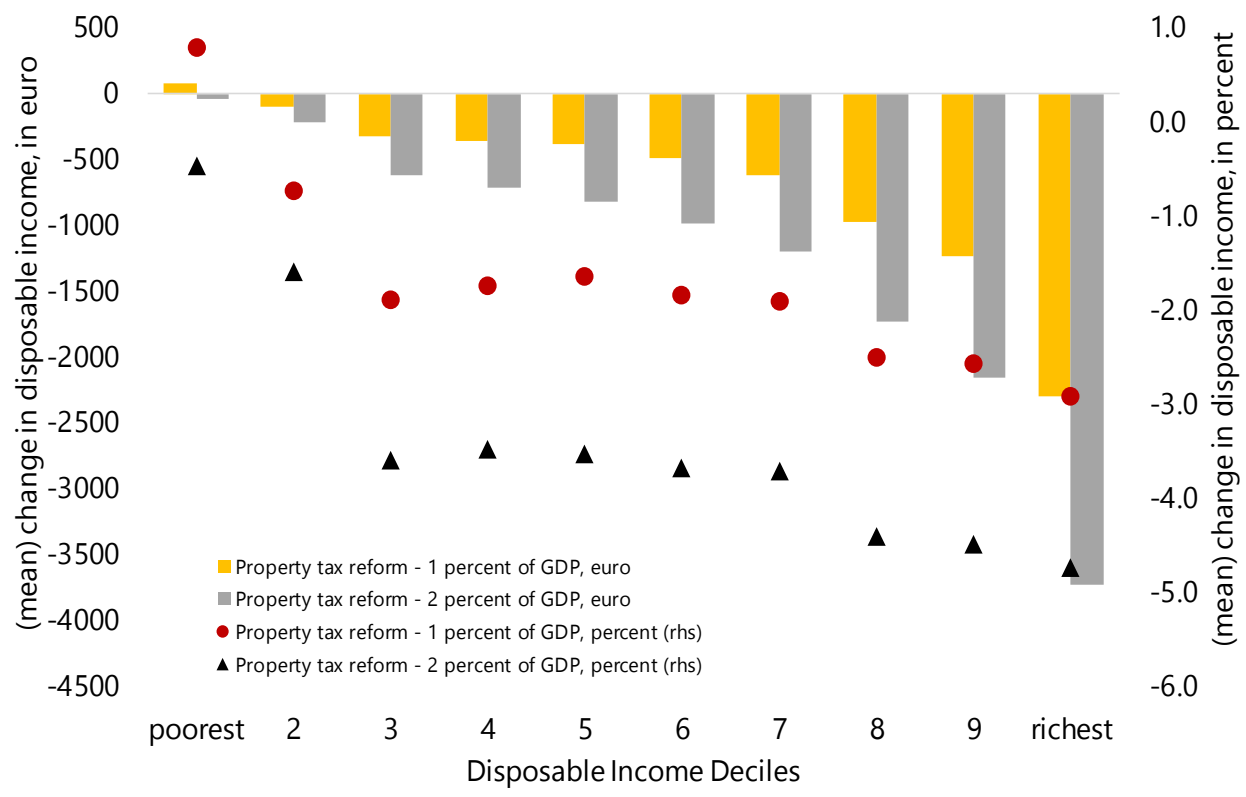

Note: This chart displays the change in the property tax liability as a result of the proposed reform, measured as the change in disposable income both in monetary values (euro); and in percentage of disposable income. The reform is calibrated assuming market-based valuation and a tax rate of 0.55 percent (and 0.8 percent) on all properties for an increase of 1 percent of GDP (and 2 percent of GDP) in tax revenue. The change in the tax liability is relative to the current cadastral valuation system, in which main residences are exempt.

Sources: Authors' calculations based EUROMOD.

Figure 12. Property Tax Liability Before and After Reform

(In percent of household disposable income)

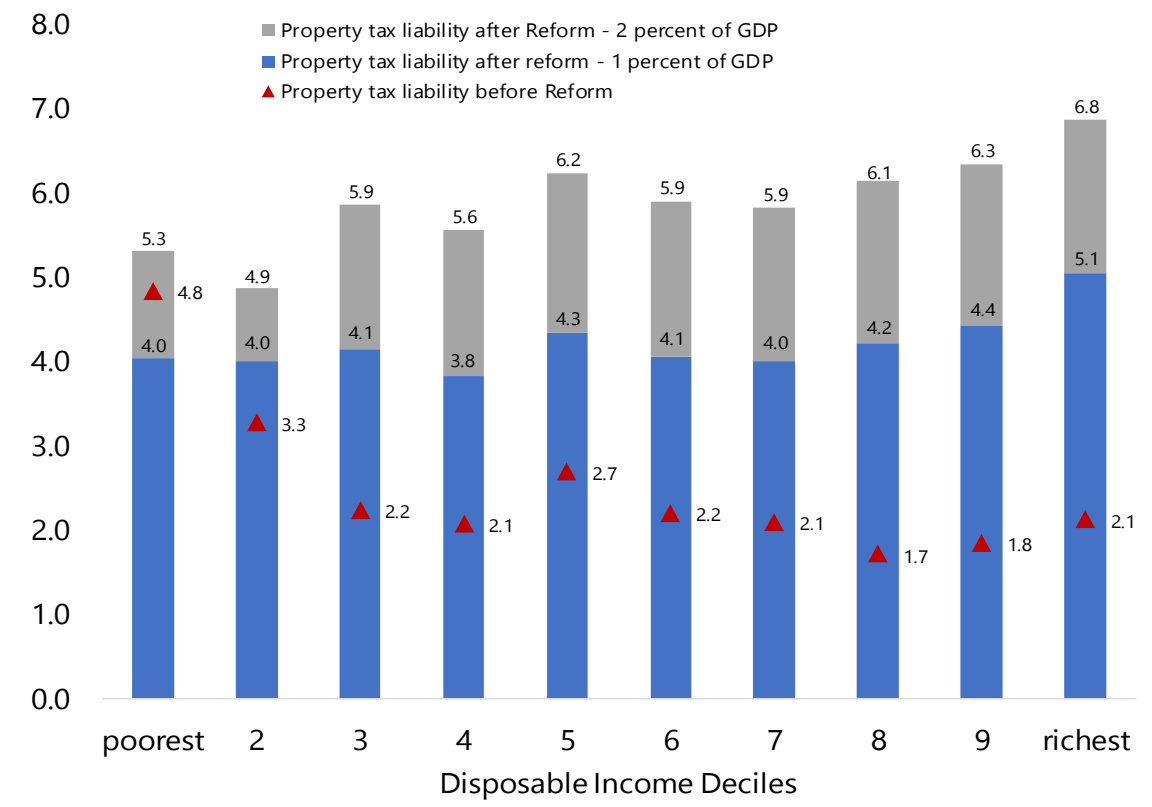

Sources: Authors' calculations based on EUROMOD. 


\section{Distributive Effects of a Revenue-Neutral Shift in Taxation}

This section presents the combined effect on income distribution of a revenue-neutral tax shift from labor income to consumption and property taxation. Three alternative options are considered to finance a PIT reform that lowers the tax burden on labor income by the equivalent of 2 percent of GDP in budget revenue: (1) fully financed through the proposed VAT reform; (2) equally financed through the proposed VAT and property tax reforms; or (3) fully financed through the proposed property tax reform.

A revenue-neutral shift from PIT to VAT benefits middle- to higher-income households.

Disposable income of middle-income households (from third to seventh deciles of the income distribution) increases with the proposed reform by 2.5 percent on average (Figure 13). This is equivalent to an average annual tax relief of $€ 620$ per household. The reform also benefits-but to a lesser extent-wealthier households in the highest three deciles. Their disposable income increases by an average 0.8 percent (or $€ 250$ ). In contrast, however, given that a revenueincreasing VAT reform is regressive, low-income households (in the first two deciles) are worseoff with this reform. Their disposable income decreases on average by 1 percent (or €100).

\section{Figure 13. Impact of a Revenue-Neutral Shift from Income Tax to VAT}

(Change in household disposable income, in percent)

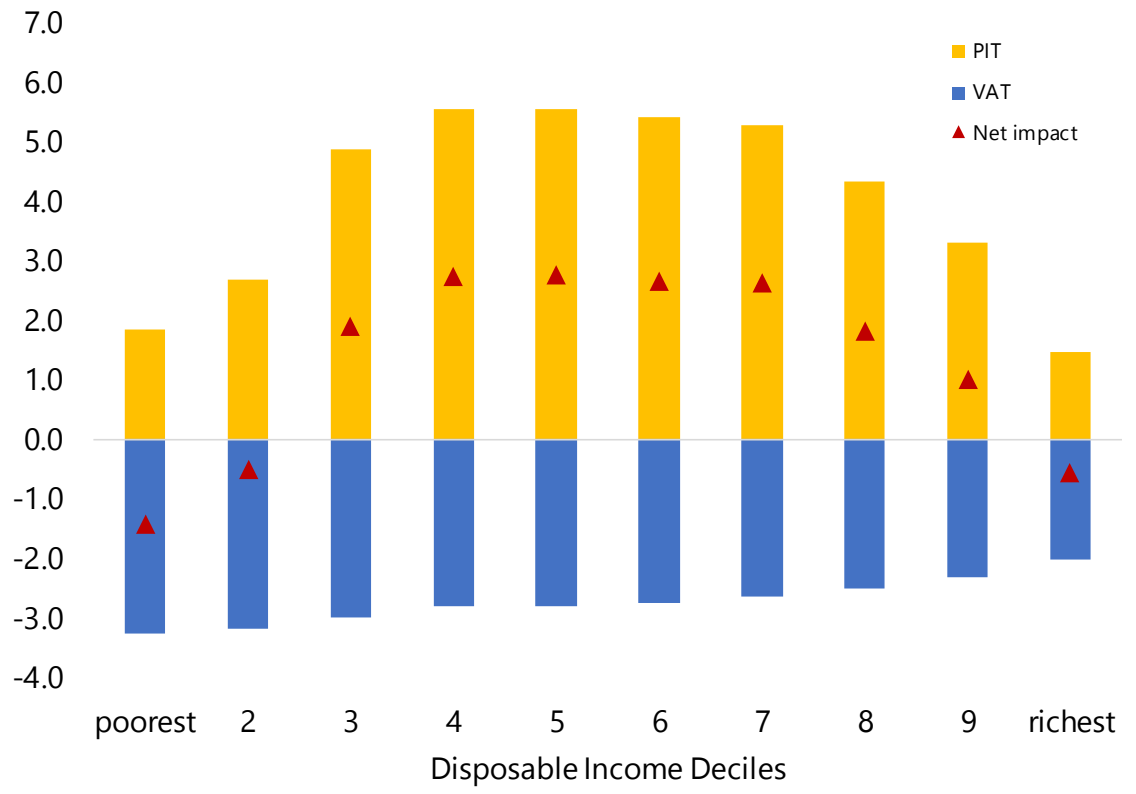

Note: This chart displays the change in the tax liability as a result of the proposed reform, measured in percentage of disposable income. The reform is calibrated for a revenue-neutral shift equivalent to 2 percent of GDP in budget revenue from the personal income tax (Reform 1) to VAT. The yellow bars show the effect of the PIT reform 1 as discussed in Section A. The blue bars show the effect of eliminating the VAT reduced rate of 10 percent in combination with an increase of the standard rate to 24 percent.

Sources: Authors' calculations based on EUROMOD and own micro-simulation model.

A revenue-neutral shift from PIT to VAT and property tax still benefits middle-income households the most, while it is relatively neutral on low-income households. Disposable income of middle- 
income households increases with the proposed reform by 2.0 percent on average (or $€ 500$ ) (Figure 14). In addition, the reform is neutral to slightly positive on low-income households. Their disposable income increases by an average 0.6 percent (or $€ 60$ ). In this case, the cost of the reform is assumed by high-income households for which disposable income decreases on average by 0.7 percent (or $€ 600$ ). The shift from VAT to property tax in this reform scenario adds progressivity to the system, resulting in a lower increase in disposable income among middleincome households, and a decrease in disposable income among high-income households.

Figure 14. Impact of a Revenue-Neutral Shift from Income Tax to VAT and Property Tax (Change in household disposable income, in percent)

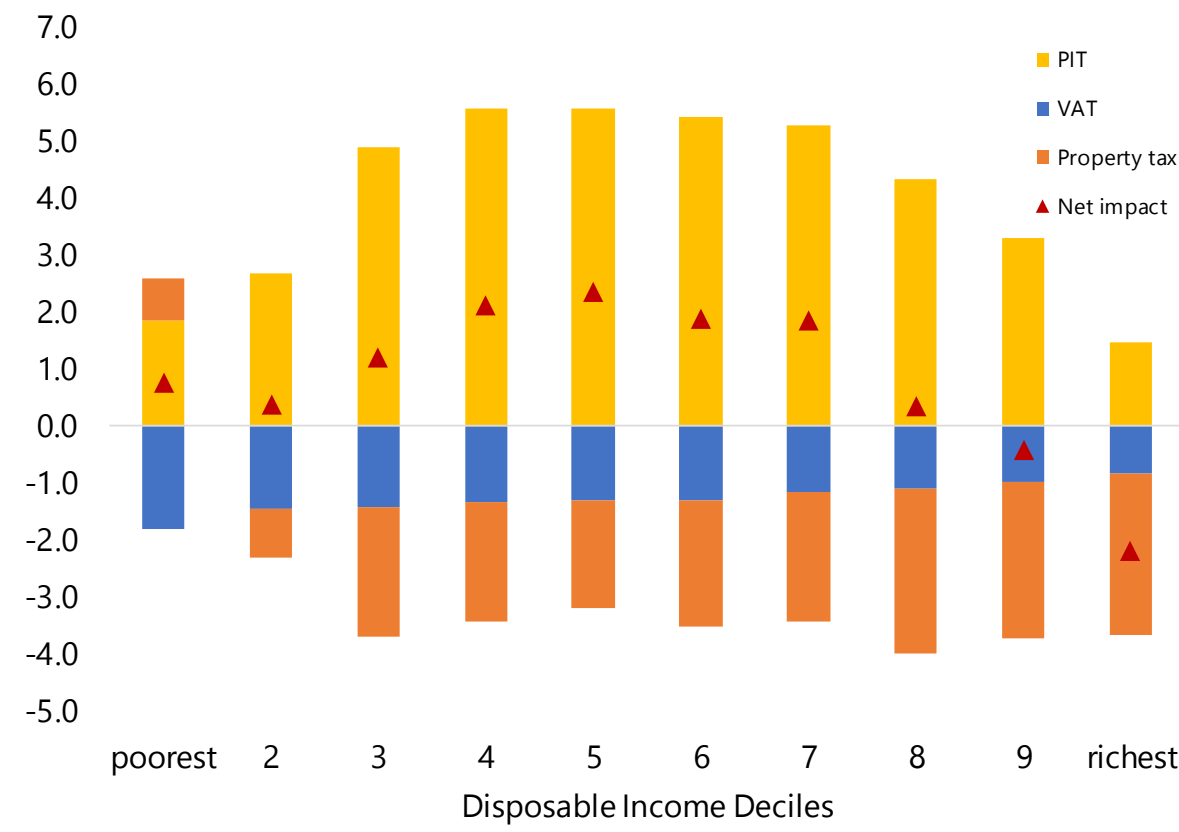

Note: This chart displays the change in the tax liability as a result of the proposed reform, measured in percentage of disposable income. The reform is calibrated for a revenue-neutral shift equivalent to 2 percent of GDP in budget revenue from the personal income tax (Reform 1) to VAT (1 percent of GDP) and property tax (1 percent of GDP). The yellow bars show the effect of the PIT reform 1 as discussed in Section A. The blue bars show the effect of eliminating the VAT reduced rate of 10 percent in combination with a reduction of the standard rate to 21 percent, to generate additional revenue of about 1 percent of GDP. The orange bars show the effect of the 1 percent of GDP base-broadening property tax reform presented in Section C.

Sources: Authors' calculations based on EUROMOD and own micro-simulation model.

Finally, a revenue-neutral shift from PIT to property tax benefits low- and middle-income households equally. In this case, the disposable income of low- and middle-income households increases, on average, by 1.4 and 1.7 percent, respectively (Figure 15). The cost of the reform under this scenario is mostly assumed by high-income households for which disposable income decreases on average by 1.5 percent. Without higher VAT revenue, the progressivity of the tax system increases the most. The percentage change in disposable income decreases strongly relative to income and becomes negative from the $8^{\text {th }}$ decile onwards. 
Figure 15. Impact of a Revenue-Neutral Shift from Income to Property Tax

(Change in household disposable income, in percent)

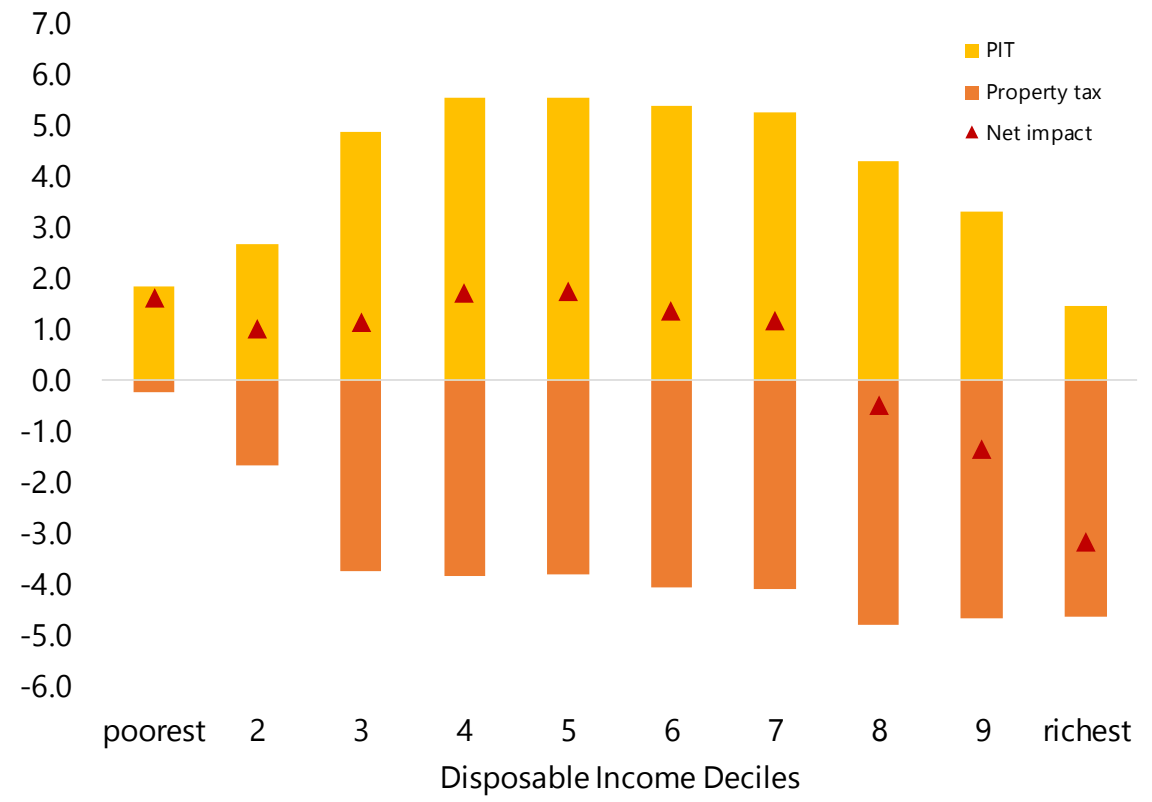

Note: This chart displays the change in the tax liability as a result of the proposed reform, measured in percentage of disposable income. The reform is calibrated for a revenue-neutral shift equivalent to 2 percent of GDP in budget revenue from the personal income tax (Reform 1) to property tax. The yellow bars show the effect of the PIT reform 1 as discussed in Section A. The orange bars show the effect of the 2 percent of GDP base-broadening property tax reform presented in Section C.

Sources: Authors' calculations based on EUROMOD and own micro-simulation model.

\section{CONCLUSIONS AND POLICY IMPLICATIONS}

Governments need to make a choice about the tax base and tax rates that will help them meet a revenue target. A central argument in public economics is that higher marginal tax rates increase the distorting effects of the tax system and thus the deadweight loss to the economy (Feldstein, 2014). A broader tax base, in combination with low tax rates, is therefore desirable. In reality, however, special interests (from specific sectors, activities, regions, or agents) are often able to secure a tax break, each of which has only minor implications for the overall efficiency-and revenue-but combined may bring significant dead-weight losses. As revenue needs increase, the efficiency costs of a narrow tax base and high marginal tax rates increase exponentially (Ilzetzky, 2018).

Inefficiencies in the Italian tax code point to the benefits of a comprehensive base-broadening tax reform. Tax expenditures are very costly in terms of foregone revenue. The resulting erosion of the tax base has increased the need for governments to rely on higher marginal rates, especially on labor income. Inefficiency and the overall complexity of the tax system have contributed to a significant compliance gap that further erodes revenue collection. To facilitate broad-based growth and to put the current very high level of public debt on a firm downward path, Italy faces revenue needs that cannot be addressed with a narrow tax base. 
This paper assesses the revenue and distributive implications of a comprehensive tax reform for Italy with the objective of reducing the tax burden on labor income toward the EU average. Reform options are guided by the principles of reducing complexity, broadening the tax base, and lowering marginal tax rates. The implications of alternative reform proposals assessed in this paper based on microsimulation methods can be summarized as follows:

- $\quad$ Lowering the tax burden on labor income through a personal income tax reform that preserves its current progressive structure-unlike a flatter structure-would benefit lowand middle-income households the most. The PIT structure can be simplified by lowering the number of taxable income brackets. The cost of the proposed reform can be partially compensated by streamlining certain tax credits and deductions that are either poorly targeted or produce negative labor supply incentives.

- $\quad$ A base-broadening VAT reform needs to be carefully designed to limit negative distributive effects. Several goods and services currently subject to reduced rates are largely consumed by wealthier families. As such a revenue-neutral VAT reform that eliminates the reduced rate of 10 percent while compensating consumers with a lower standard rate is almost neutral in terms of the income distribution.

- Updating the property valuation system for the property tax is essential to address equity concerns and increase revenue collection. The current use of an outdated cadastral valuation system to determine immovable property tax liabilities significantly erodes the tax base, while imposing a disproportionately high tax burden on the poor. A reform to the valuation system that addresses the gap between market and taxable values would significantly raise the progressivity of the tax. As a result, substantially more revenue can be collected, with lower tax rates.

- $\quad$ A revenue-neutral tax reform that shifts revenue from labor income to consumption and property can be designed to benefit low- and middle-income households the most. A reform of the personal income tax, the VAT, and the tax on immovable property can be designed to achieve a revenue-neutral reduction of the tax burden on labor income toward the EU average. Broadening the tax base while reducing marginal tax rates also lowers the overall current tax liability on low- and middle-income households.

The implications of the proposed comprehensive tax reform for Italy may go beyond the analysis presented here. As mentioned in the introduction, there is strong evidence that a tax reform aimed at reducing complexity and lowering marginal tax rates can also help address large tax compliance gaps. This, however, would require a holistic strategy to strengthen the efforts of the tax administration to assist with the implementation and enforcement of any tax policy changes. A detailed assessment of the key organizational and operational aspects of the Italian tax administration that would need to be strengthened to support tax compliance efforts is beyond the scope of this paper. 


\section{APPENDIX}

As mentioned in Section II, a matching procedure is proposed, following Sanchez and others (2016), that imputes data on household expenditures from the Italian Household Budget Survey (HBS) of 2017 into the EU-SILC database. To do that, data from the Survey on Household Income and Wealth (SHIW) of 2016 from the Bank of Italy is used, that contains data on income and consumption, but only at an aggregated level. The imputation and matching strategy is based on the following steps:

1. Estimating a consumption function using the SHIW dataset. A regression model is used to estimate aggregated household consumption expenditure (in logs) on disposable income (in logs) and a set of household-specific control variables or covariates that are also available in the EU-SILC dataset (Appendix Table 1).

\begin{tabular}{|c|c|c|c|}
\hline \multicolumn{4}{|c|}{ Appendix Table 1. Consumption Function in SHIW } \\
\hline Income (logs) & $\begin{array}{l}-0.789^{\star \star *} \\
(0.037)\end{array}$ & Household Size = 2 & $\begin{array}{l}0.063^{\star * *} \\
(0.010)\end{array}$ \\
\hline Income Squared (logs) & $\begin{array}{l}0.069 * * * \\
(0.002)\end{array}$ & Household Size $=3$ & $\begin{array}{l}0.083^{* * *} \\
(0.015)\end{array}$ \\
\hline Male Household Head & $\begin{array}{l}0.007 \\
(0.007)\end{array}$ & Household Size $=4$ & $\begin{array}{l}0.099 * * * \\
(0.018)\end{array}$ \\
\hline Married Household Head & $\begin{array}{l}0.032^{* * *} \\
(0.008)\end{array}$ & Household Size $=5+$ & $\begin{array}{l}0.126^{\star * *} \\
(0.019)\end{array}$ \\
\hline Age $30-64$ & $\begin{array}{l}-0.027^{* * *} \\
(0.007)\end{array}$ & Children $=1$ & $\begin{array}{l}-0.001 \\
(0.010)\end{array}$ \\
\hline Age $65+$ & $\begin{array}{l}-0.021^{* *} \\
(0.009)\end{array}$ & Children $=2+$ & $\begin{array}{l}0.005 \\
(0.014)\end{array}$ \\
\hline Lower secondary Education & $\begin{array}{l}0.047^{\star \star *} \\
(0.007)\end{array}$ & Number of Earners & $\begin{array}{l}-0.046^{\star * *} \\
(0.005)\end{array}$ \\
\hline Upper secondary Education & $\begin{array}{l}0.074^{\star \star *} \\
(0.008)\end{array}$ & Constant & $\begin{array}{l}10.654^{\star \star \star} \\
(0.181)\end{array}$ \\
\hline Tertiary Education & $\begin{array}{l}0.095^{* * *} \\
(0.012)\end{array}$ & $\mathrm{R} 2$ & 0.599 \\
\hline Self Employed & $\begin{array}{l}-0.033^{* * *} \\
(0.013)\end{array}$ & $\begin{array}{l}\text { F-statistic } \\
\text { Observations }\end{array}$ & $\begin{array}{c}997.89 \\
16,333 \\
\end{array}$ \\
\hline
\end{tabular}

2. Imputing aggregated household consumption in EU-SILC. The estimated parameters of the consumption function are used to predict aggregated consumption using disposable income (and household-specific control variables) in the EU-SILC dataset. Appendix Table 2 compares the results of a simple regression of consumption on income and squared income (all in logs) using both SHIW and EU-SILC datasets. For the regression using the EU-SILC dataset, estimated consumption is used. The estimated coefficients are almost identical. 


\begin{tabular}{|c|c|c|c|}
\hline \multicolumn{4}{|c|}{ Appendix Table 2. Consumption Function in SHIW and in EU-SILC } \\
\hline \multicolumn{2}{|l|}{ SHIW } & \multicolumn{2}{|l|}{ EU-SILC } \\
\hline \multirow[t]{2}{*}{ Income (logs) } & $-0.811^{* * *}$ & Income (logs) & $-0.825^{\star * *}$ \\
\hline & $(0.019)$ & & $(0.006)$ \\
\hline \multirow[t]{2}{*}{ Income Squared (logs) } & $0.071^{* * *}$ & Income Squared (logs) & $0.073^{* * *}$ \\
\hline & $(0.001)$ & & $(0.001)$ \\
\hline \multirow[t]{2}{*}{ Constant } & $10.771^{\star \star \star}$ & Constant & $10.723^{* * *}$ \\
\hline & $(0.095)$ & & $(0.031)$ \\
\hline R2 & 0.587 & R2 & 0.981 \\
\hline F-statistic & 11636.3 & F-statistic & 26636.8 \\
\hline Observations & 16333 & Observations & 21704 \\
\hline
\end{tabular}

3. Matching individual households in the HBS and EU-SILC datasets. A statistical procedure is performed (using propensity score matching) to match individual households that share identical characteristics in both, the HBS and EU-SILC datasets. The matching procedure uses information on aggregated consumption (observed in the HBS and predicted in the EU-SILC dataset), as well as household-specific control variables. Appendix Table 3 presents the estimation results. To test the accuracy of the matching procedure, a propensity score (PS) test is performed. This is a t-test on the null hypothesis that the mean value of each variable is the same in the treatment group and the non treatment group, in this case the caracteristics of individual households in each dataset. It is done before and after matching. Furthermore, a bias before and after matching is calculated for each variable and the change in this bias is stated. This "bias" is defined as the diffrerence of the mean values of the treatment group and the (not matched / matched) non treatment group, devided by the square root of the average sample variance on the treatment group and the not matched non treatment group. In Appendix Table 3, one case see the difference of the values of the exogenous variables between the two groups before and after matching. By the matching, the differences between treatment group and non treatment group are reduced considerably as indicated by the change in the mean bias from 7.5 before matching to 2.4 after matching. The null hypothesis that the mean values of the two groups do not differ after matching cannot be rejected for any variable.

\section{Computing disaggregated household consumption shares in HBS and imputing them to} their respective matched households in EU-SILC. Households in the Italian HBS data report expenditures on 276 different goods and services. For the purpose of the analysis, the consumption data is aggregated into 12 different COICOP (Classification of Individual Consumption by Purpose) categories: 1) food and non-alcoholic beverages; 2) alcoholic beverages and tobacco; 3) clothing and footwear; 4) home fuels, electricity, rents (excluding imputed rents); 5) furniture and household services; 6) health; 7) transport; 8) communication; 9) recreation and culture; 10) education; 11) hospitality and catering; 12) other goods and services. The shares to total consumption expenditure are then computed in HBS for each of the 12 consumption categories, at the individual household level. Finally, the computed shares in HBS are imputed to their respective matched households in EU-SILC. Appendix Table 4 presents the consumption shares computed in HBS and their predicted values in EU-SILC. Finally, the 
matched consumption shares are multiplied with total imputed consumption in EU-SILC to obtain household consumption levels for the 12 different consumption categories. On average, imputed values in EU-SILC reflect quite closely household spending observed in HBS. Appendix Figure 1 shows the density of both observed consumption in HBS (HBS_c) and imputed consuption in EU-SILC (c), indicating that 95 percent of consumption is matched well in both datasets. In addition, the imputed shares, as well as total household consumption, are also very similar to those estimated in Sanchez and others (2016) providing further robustness.

\begin{tabular}{|c|c|c|c|c|c|}
\hline \multicolumn{6}{|c|}{ Appendix Table 3. Matching Households in HBS and EU-SILC } \\
\hline \multicolumn{2}{|l|}{ Probit Regression } & \multicolumn{3}{|c|}{ PS Test } & \multirow[b]{2}{*}{$\%$ bias } \\
\hline \multirow[t]{3}{*}{ Variable } & & Unmatched & Mean & & \\
\hline & & & & Contro & \\
\hline & & Matched & Treated & I & \\
\hline \multirow[t]{2}{*}{ Consumption } & $-0.001^{* * *}$ & $U$ & 22,675 & 22,675 & -0.0 \\
\hline & $(0.000)$ & M & 22,675 & 23,270 & $-4.1^{* \star *}$ \\
\hline \multirow[t]{2}{*}{ Male Household Head } & $-0.105^{\star}$ & $U$ & 0.613 & 0.655 & -8.7 \\
\hline & $(0.015)$ & M & 0.613 & 0.604 & $1.9 * *$ \\
\hline \multirow[t]{2}{*}{ Married Household Head } & $-0.044^{*}$ & U & 0.494 & 0.527 & -6.7 \\
\hline & $(0.015)$ & M & 0.494 & 0.499 & $-1.0 * \star *$ \\
\hline \multirow[t]{2}{*}{ Age $30-64$} & -0.843 & $U$ & 0.429 & 0.541 & -22.7 \\
\hline & $(0.021)$ & M & 0.429 & 0.422 & $1.3^{* \star \star}$ \\
\hline \multirow[t]{2}{*}{ Age $65+$} & -0.707 & $U$ & 0.365 & 0.394 & -6.1 \\
\hline & $(0.023)$ & M & 0.365 & 0.371 & $-1.3^{* * *}$ \\
\hline \multirow[t]{2}{*}{ Lower secondary Education } & $0.051^{* * *}$ & U & 0.259 & 0.283 & -5.6 \\
\hline & $(0.020)$ & M & 0.259 & 0.268 & $-2.1^{\star}$ \\
\hline \multirow[t]{2}{*}{ Upper secondary Education } & $0.142^{*}$ & $U$ & 0.384 & 0.342 & 8.8 \\
\hline & $(0.020)$ & M & 0.384 & 0.390 & $-1.3^{* * *}$ \\
\hline \multirow[t]{2}{*}{ Tertiary Education } & $0.127^{*}$ & $U$ & 0.163 & 0.148 & 4.1 \\
\hline & *0.024) & M & 0.163 & 0.153 & $2.7^{*}$ \\
\hline \multirow[t]{2}{*}{ Self Employed } & $0.073^{* *}$ & $U$ & 0.162 & 0.144 & 4.9 \\
\hline & $(0.018)$ & M & 0.162 & 0.140 & $6.2^{*}$ \\
\hline \multirow[t]{2}{*}{ Constant } & 0.834 & & & & \\
\hline & $(0.028)$ & & & & \\
\hline Pseudo R2 & 0.036 & $U$ & \multirow[t]{2}{*}{ Pseudo R2 } & & 0.036 \\
\hline LR chi2 prob. & 0.000 & M & & & 0.002 \\
\hline \multirow[t]{4}{*}{ Observations } & 38,650 & $U$ & \multirow[t]{2}{*}{ LR chi2 prob. } & & 0.000 \\
\hline & & M & & & 0.000 \\
\hline & & $U$ & \multirow[t]{2}{*}{ Mean Bias } & & 7.5 \\
\hline & & $M$ & & & 2.4 \\
\hline $\begin{array}{l}\text { Notes: Probit regression was p } \\
* * *(* *, *) \text { indicate significance at } \\
\text { hypothesis that the mean value } \\
\text { group. It is done before and af } \\
1(5,10) \text { percent. }\end{array}$ & $\begin{array}{l}\text { rmed using } \\
5,10) \text { percer } \\
\text { each varial } \\
\text { matching. * }\end{array}$ & $\begin{array}{l}\text { command in S } \\
\text { pensity score } \\
\text { me in the treat } \\
\text { ate that the } n\end{array}$ & $\begin{array}{l}\text { ata. Standard e } \\
\text { est (PS test), a t } \\
\text { ment group and } \\
\text { ll hypothesis ca }\end{array}$ & $\begin{array}{l}\text { rs in pa } \\
\text { est on th } \\
\text { hen non } \\
\text { not be re }\end{array}$ & $\begin{array}{l}\text { ntheses, } \\
\text { null } \\
\text { reatment } \\
\text { ected at }\end{array}$ \\
\hline
\end{tabular}




\begin{tabular}{|c|c|c|c|c|c|c|}
\hline \multicolumn{7}{|c|}{ Appendix Table 4. Consumption Shares in HBS and EU-SILC } \\
\hline & \multicolumn{3}{|c|}{ HBS } & \multicolumn{2}{|c|}{ EU-SILC } & \multirow[b]{2}{*}{$\begin{array}{l}\text { Household } \\
\text { Consumption }\end{array}$} \\
\hline & Mean & $\begin{array}{l}\text { Std. } \\
\text { Dev. }\end{array}$ & $\begin{array}{l}\text { Household } \\
\text { Consumption }\end{array}$ & Mean & $\begin{array}{l}\text { Std. } \\
\text { Dev. }\end{array}$ & \\
\hline Food and non-alcoholic beverages & 27.2 & 13.5 & 466.4 & 26.1 & 12.4 & 452.8 \\
\hline Alcoholic beverages and Tobacco & 2.4 & 4.1 & 44.3 & 2.5 & 3.9 & 47.3 \\
\hline Clothing and footwear & 5.5 & 7.4 & 122.6 & 5.7 & 7.3 & 115.0 \\
\hline Home fuels, electricity, rents & 18.9 & 14.3 & 309.1 & 18.2 & 13.5 & 314.5 \\
\hline Furniture and household services & 4.9 & 7.4 & 111.2 & 5.2 & 7.8 & 99.5 \\
\hline Health & 6.4 & 8.5 & 123.8 & 6.1 & 8.1 & 110.9 \\
\hline Transport & 11.8 & 12.3 & 287.4 & 11.9 & 11.9 & 256.8 \\
\hline Communication & 3.6 & 3.1 & 64.0 & 3.5 & 2.8 & 63.0 \\
\hline Recreation and culture & 5.3 & 6.5 & 131.1 & 5.8 & 6.7 & 124.1 \\
\hline Education & 0.6 & 2.1 & 15.7 & 0.6 & 2.1 & 13.8 \\
\hline Hospitality and catering & 5.0 & 7.0 & 120.8 & 5.6 & 7.2 & 120.2 \\
\hline Other & 8.4 & 7.3 & 180.6 & 8.8 & 7.3 & 171.7 \\
\hline Observations & \multicolumn{2}{|c|}{16946} & & \multicolumn{2}{|c|}{21704} & \\
\hline
\end{tabular}

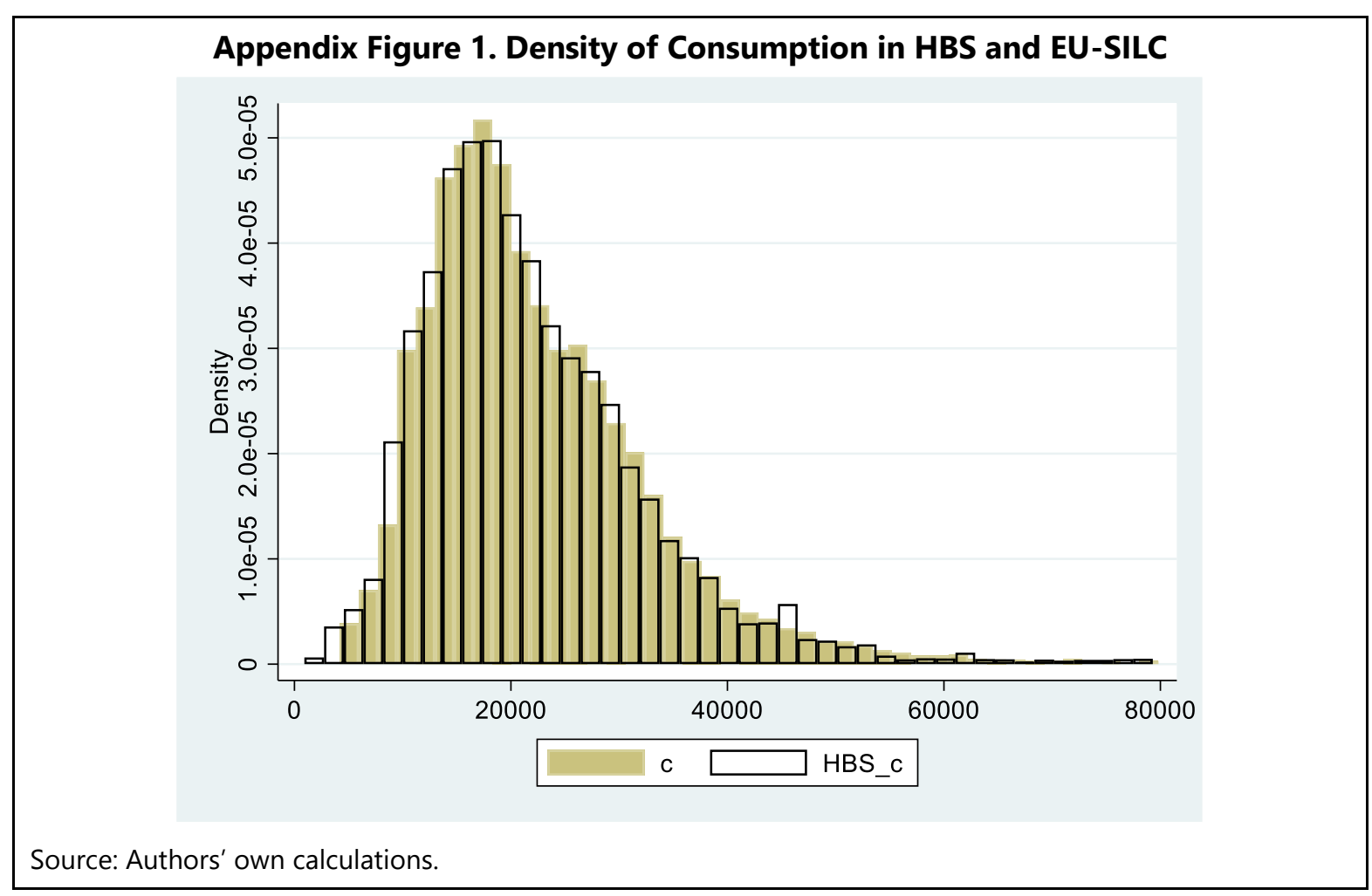




\section{Measuring inequality using household consumption}

As suggested in earlier literature, using current income for tax incidence analysis may lead to measurement problems. Following Friedman (1957) and the permanent income hypothesis, there was a realization that consumption decisions are made over a longer time horizon. Following Poterba (1989), current consumption can be used as a proxy for permanent income, since if consumer behavior is consistent with the permanent income hypothesis, then consumers would set current consumption proportional to permanent income. Using household consumption instead of disposable income results in a somewhat more progressive tax system in Italy (Appendix Figure 2). The baseline PIT liability increases from 1.7 to 42 percent; the VAT liability is relatively flat, increasing from 12.3 to 13 percent; while the property tax liability decreases from 4.6 to 2.7 percent.

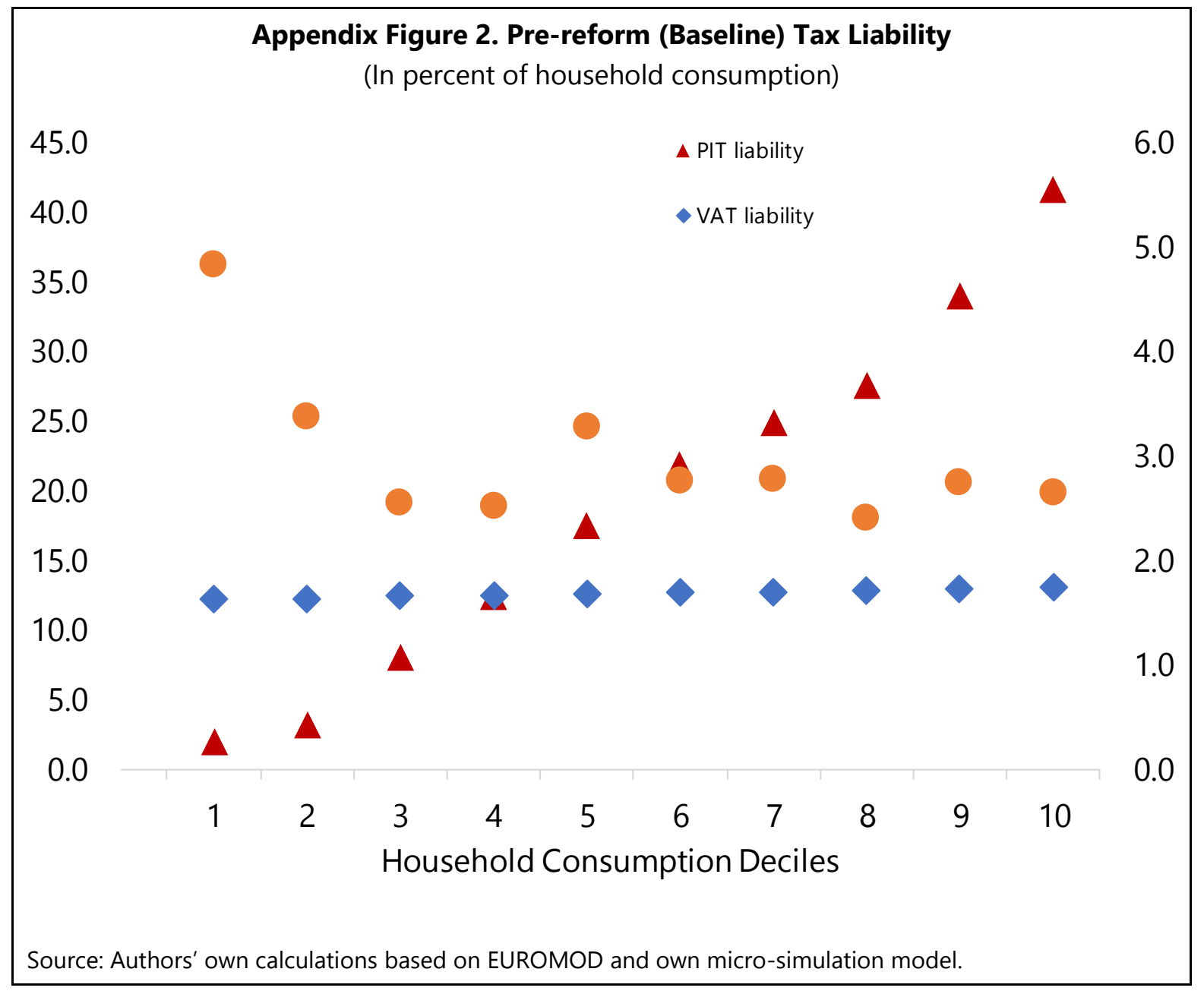

As a result, for example, a revenue-neutral shift away from income tax and toward VAT and property tax results in a slightly higher benefit for middle-income households (Appendix Figure 3). The net impact of the reform represents an increase in household consumption of about 3.6 percent $(€ 700)$ for middle-income households (from third to seventh deciles). The impact on both low- and high-income households is almost unchanged. 


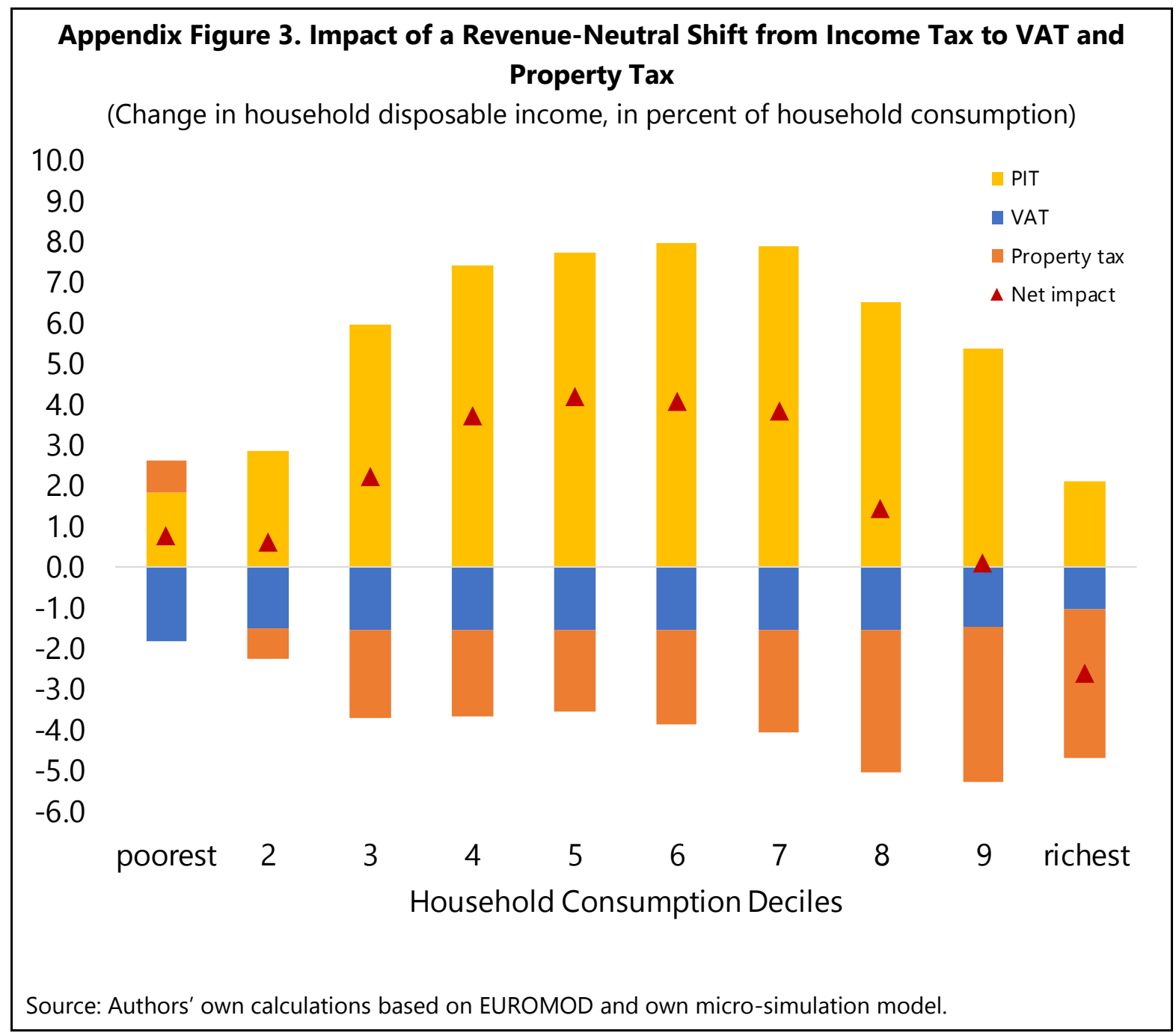

\section{REFERENCES}

Abeler, J. and S. Jaeger, 2015, "Complex tax incentives," American Economic Journal: Economic Policy 7 (3), 1-28.

Agenzia delle Entrate, 2017, "Gli immobili in Italia: Ricchezza, reddito, e fiscalita immobiliare," https://www.agenziaentrate.gov.it/portale/web/guest/agenzia/agenzia-comunica/prodottieditoriali/pubblicazioni-cartografia catasto mercato immobiliare/immobili-in-italia/gliimmobili-in-italia-2017

Aghion, P., U. Akcigit, M. Lequien, and S. Stantcheva, 2017, "Tax simplicity and heterogeneous learning. Technical report," National Bureau of Economic Research.

Andrle, M., S. Hebous, A. Kangur, and M. Raissi, 2018, "Italy: Toward a growth-friendly fiscal reform," IMF Working Paper 18/59, (Washington: International Monetary Fund). 
Arnold, J., B. Brys, C. Heady, A. Johansson, C. Schwellnus, and L. Vartia, 2011, "Tax policy for economic recovery and growth," The Economic Journal, 121 (550), 59-80.

Baiardi, D., P. Profeta, R. Puglisi, and S. Scabrosetti, 2019, "Tax policy and economic growth: Does it really matter?" International Tax and Public Finance, 26 (2), 282-316.

Baldini, M., and L. Rizzo, 2018, "Anche la "quasi" flat tax costa 50 miliardi," Lavoce.info. May 15, 2018.

Bank of Italy (BOI), 2019, "Annual Report for 2018," https://www.bancaditalia.it/ pubblicazioni/relazione- annuale /2018/en rel 2018.Pdf ?language id=1

Capeau, B., A. Decoster, and D. Phillips, 2014, "Consumption and indirect tax models," Handbook of Microsimulation Modelling, Emerald Group Publishing, Bingley, UK, 223-58.

Center for Social and Economic Research (CASE), 2018. Study and Reports on the VAT Gap in the EU 28 Member States: 2018 Final Report. CASE network Studies and Analyses, TAXUD/131.

Ceriani, L., F. Figari, and C. Fiorio, 2015,"Italy 2011-2015," EUROMOD Country Report, https://www.euromod.ac.uk/sites/default/files/country-reports/year6/Y6 CR IT final 08-032016.pdf

Chetty, R. and E. Saez, 2013, "Teaching the tax code: Earnings responses to an experiment with EITC recipients," American Economic Journal: Applied Economics 5 (1), 1-31.

Chiarini B., E. Marzano, and F. Schneider, 2013, "Tax rates and tax evasion: an empirical analysis of the long-run aspects in Italy," European Journal of Law and Economics, 35 (2).

Curci, N., and M. Savegnano, 2019, "Shifting taxes from labor to consumption: the efficiencyequity trade-off," Bank of Italy Working Paper 1244, November.

European Commission (EC), 2006, "Macroeconomic effects of a shift from direct to indirect taxation: a simulation for 15 EU member states" (Brussels: European Commission, DG TAXUD).

European Commission (EC), 2010, "The proposals for country surveillance in Europe-2020: exploiting existing LIME tools to contribute to more integrated surveillance on the impact of structural reforms on potential output, public finances, and current account positions" (Brussels: European Commission, DG ECFIN).

European Commission (EC), 2012a, "A study on the economic effects of the current VAT rates structure," Final Report TAXUD/2012/DE/323 (Brussels: European Commission, TAXUD).

European Commission (EC), 2012b, "Possible reforms of real estate taxation: Criteria for successful policies," Occasional Papers 119 (Brussels: European Commission, DG ECFIN). 
European Commission (EC), 2016, "The fiscal and equity impact of tax expenditures in the European Union," JRC Working Papers on taxation and structural reforms 1/2016 (Brussels: European Commission, The Joint Research Center).

Feldstein, M., 2014, "Raising revenue by limiting tax expenditures," NBER Working Paper 20672, National Bureau of Economic Research.

Freire-Seren, M., and J. Panades, 2013, "Do higher tax rates encourage/discourage tax compliance?" Modern Economy, 4, 809-17.

Friedman, M., 1957, "A Theory of the Consumption Function." Princeton University Press.

Heady, C., and M. Mansour, 2019, "Tax Expenditure Reporting and Its Use in Fiscal Management," Fiscal Affairs Department How-to-Notes 19/01, (Washington: International Monetary Fund).

Ilzetzky, E., 2018, "Tax reform and the political economy of the tax base," Journal of Public Economics 164, 197-210.

Impact Assessment Office, 2017, "The effective tax rates jungle," Documento di valutazione 1, Senato della Repubblica, Ufficio Valutazione Impatto, https://www.senato.it/application/ xmanager/projects/leg17/attachments/documento/files/000/028/530/AME Dossier compl eto copertina ENG.pdf

International Monetary Fund (IMF), 2012, "Italy: The Delega Fiscale and the strategic orientation of tax reform," IMF Country Report 12/280 (Washington: International Monetary Fund).

International Monetary Fund (IMF), 2015, "Fiscal Policy and long-term growth," IMF Policy Paper (Washington: International Monetary Fund).

International Monetary Fund (IMF), 2019, "Reforming Italy's Social Welfare System and Lowering Taxes on Labor: Some Considerations," IMF Country Report 19/41 (Washington: International Monetary Fund).

Institute of Fiscal Studies (IFS), 2011, "A retrospective evaluation of elements of the EU VAT system," Final Report 2010/DE/328, Commissioned by the European Commission, DG TAXUD.

Mankiw, N., M. Weinzierl, and D. Yagan, 2009, "Optimal taxation in theory and practice," Journal of Economic Perspectives, 23 (4), 147-74.

Ministry of Economy and Finance (MEF), 2018, "Rapporto programmatico recante gli interventi in materia di spese fiscali," Nota di aggiornamento del Documento di Economia e Finanza 2018, Republic of Italy.

Ministry of Economy and Finance (MEF), 2019a, "Relazione sull'economia non osservata e sull'evasione fiscale e contributive," Nota di aggiornamento del Documento di Economia e Finanza 2019, Republic of Italy. 
Ministry of Economy and Finance (MEF), 2019b, "Rapporto programmatico recante gli interventi in materia di spese fiscali," Nota di aggiornamento del Documento di Economia e Finanza 2019, Republic of Italy.

Myles, G, 2009, "Economic growth and the role of taxation-aggregate data," OECD Economics Department Working Paper 714, (Paris: Organization for Economic Co-Operation and Development).

Organization for Economic Co-Operation and Development (OECD), 2010, "Tax Expenditures in OECD countries," OECD Publishing, Paris.

Pisani, S., 2014, "An approach to assess how the activity of the Italian revenue agency affects compliance," Discussion Topics 1/2014, Agenzia delle Entrate.

Poterba, J. 1989, "Lifetime Incidence and the Distributional Burden of Excise Taxes," The American Economic Review, 79 (2), Papers and Proceedings of the Hundred and First Annual Meeting of the American Economic Association (May), 325-30.

Sanchez, O., P. de Agostini, F. Figari, C. Fiorio, C. Gigliarano, K. Manios, and H. Sutherland, 2016, "Tax shifting of direct and indirect taxation in Italy and Spain," Final Report, Institute for Social and Economic Research (ISER), University of Essex.

Slemrod, J., 1990, "Optimal taxation and optimal tax systems," Journal of Economic Perspectives, 4 (1), 157-78.

Slemrod, J., 2018, "Tax compliance and enforcement," NBER Working Paper 24799, National Bureau of Economic Research.

Sutherland, H., and F. Figari, 2013, "EUROMOD: the European Union tax-benefit microsimulation model," International Journal of Microsimulation 6 (1), 4-26.

Tyson, J., 2014, "Reforming tax expenditures in Italy: What, why, and how?" IMF Working Paper 14/7 (Washington: International Monetary Fund). 